\title{
Nerve Growth Factor Induces Apoptosis in Human Medulloblastoma Cell Lines that Express TrkA Receptors
}

\author{
Yoshihiro Muragaki, ${ }^{1,2}$ Thomas T. Chou, ${ }^{1}$ David R. Kaplan, ${ }^{3}$ John Q. Trojanowski, ${ }^{1}$ and Virginia M.-Y. Lee ${ }^{1}$ \\ ${ }^{1}$ Department of Pathology and Laboratory Medicine, The University of Pennsylvania School of Medicine, Philadelphia, \\ Pennsylvania 19104-4283, 2Department of Neurosurgery, Tokyo Women's Medical College, Tokyo, Japan, and ${ }^{3}$ The \\ ABL-Basic Research Program, National Cancer Institute, Frederick Cancer Research and Development Center, Frederick, \\ Maryland 21702
}

Neurotrophins act through their cognate receptors to promote the differentiation and/or survival of neuronal progenitor cells, immature neurons, and other cells. Here, we examined the effects of nerve growth factor (NGF) and its cognate receptor (Trk or TrkA) on the survival of a common childhood brain tumor, i.e., medulloblastoma, a tumor that resembles CNS neuroepithelial progenitor cells. To do this, we engineered two human medulloblastoma cell lines (i.e., D283MED and DAOY cells) to express human TrkA using a retroviral expression vector. Surprisingly, NGF-treated medulloblastoma cells expressing the TrkA receptor (D283trk and DAOYtrk cells) grown in the presence or absence of serum underwent massive apoptosis, but similar treatment did not induce apoptosis in wildtype uninfected cells, cells expressing an empty vector, or cells expressing the TrkC receptor. Furthermore, D283MED cells engineered to express the human p75 NGF receptor (D283p75) also did not undergo apoptosis. Significantly, NGF-induced apoptosis in D283trk and DAOYtrk cells can be inhibited by anti-NGF antibodies and by K-252a, an inhibitor of TrkA tyrosine phosphorylation and mimicked by high concentrations of NT3. Because NGF treatment primarily eliminated D283trk cells from the $S$ phase of the cell cycle, this form of NGF-mediated apoptosis is cell cycle-dependent. These findings suggest that a NGF/TrkA signal transduction pathway could activate apoptotic cell death programs in CNS neuroepithelial progenitor cells and in childhood brain tumors.

Key words: nerve growth factor; neurotrophins; medulloblastoma; TrkA; apoptosis; S phase
Nerve growth factor (NGF) is the most well-studied representative of a family of trophic factors (neurotrophins), and NGF has pleiotrophic effects including the ability to induce differentiation, support cell survival, and prevent apoptosis in neuronal progenitor cells and immature neurons of the CNS and PNS (LeviMontalcini and Angeletti, 1968; Greene and Tischler, 1976; Unsicker et al., 1978; Doupe et al., 1985; Li et al., 1995). Furthermore, NGF also acts as a mitogen for neuronal precursors or endocrine cells (Lillien and Claude, 1985; Tischler et al., 1993). Two different receptors for NGF have been identified including the $\mathrm{p} 75^{\mathrm{LNGFR}}$ or p75 receptor (Chao et al., 1986; Chao and Hempstead, 1995), a transmembrane protein with no identifiable cytoplasmic catalytic domain (Johnson et al., 1986; Radeke et al., 1987), and the Trk receptor (also known as TrkA), a transmembrane protein with a cytoplasmic tyrosine kinase domain (Kaplan et al., 1991a; Klein et al., 1991a). Recent studies have shown that

\footnotetext{
Received Aug. 9, 1996; revised Oct. 17, 1996; accepted Oct. 23, 1996.

This work was supported in part by grants from National Institutes of Health and by a Zenith Award from the Alzheimer's Association. We thank Mr. N. Timothy and Mr. S. Chiu for technical assistance, Drs. D. Bigner and H. Friedman for the D283MED cell line, Dr. J. M. Verdi for the pLVSHDtrk retroviral vector, Dr. J. Wolfe for the GPenvamp12 packaging cell line, Dr. L. A. Greene for the PC12 $12^{\text {nnr5 }}$ subline, Dr. M. V. Chao for NIH-3T3trk cells, and Dr. B. Hempstead for PC12-615 cells. We also thank Mr. J. C. Mills and Dr. R. Pittman for their comments on this paper and their assistance with Hoechst staining and videomicroscopy, and Drs. J. Peringa, S. Wang, and K.-M. Fung for help with methods to detect apoptosis.

Correspondence should be addressed to Dr. Virginia M.-Y. Lee, Department of Pathology and Laboratory Medicine, University of Pennsylvania School of Medicine, HUP, Maloney Building, Room A009, Philadelphia, PA 19104-4283.

Dr. Kaplan's present address: Montreal Neurological Institute, 3801 University Street, Field House, Montreal, Quebec, Canada H3A 2B4.

Y.M. and T.T.C. contributed equally to this work.

Copyright (C) 1997 Society for Neuroscience $\quad 0270-6474 / 97 / 170530-13 \$ 05.00 / 0$
}

TrkA is essential for NGF-mediated signal transduction (CordonCardo et al., 1991; Hempstead et al., 1992; Kaplan et al., 1991a,b; Klein et al., 1991a; Loeb et al., 1991). TrkA is a member of a family of high-affinity tyrosine kinase receptor proteins that mediate the biological effects of neurotrophins. Other members of this family include TrkB and TrkC (Klein et al., 1991b; Lamballe et al., 1991; Barbacid, 1995).

Although the role of the different neurotrophin receptors in transducing signals induced by neurotrophins is beginning to be elucidated, the possible roles of neurotrophins in the induction and progression of tumors remain speculative. Analysis of two common childhood tumors of the PNS and CNS, i.e., neuroblastomas and medulloblastomas, respectively, demonstrate that these tumors express one or more neurotrophins and neurotrophin receptors (Nakagawara et al., 1992; Segal et al., 1994; Washiyama et al., 1996). Furthermore, the levels of $\operatorname{trk} A$ mRNA in neuroblastomas (Nakagawara et al., 1993) and the levels of trkC mRNA in medulloblastomas (Segal et al., 1994) correlate with improved survival. However, the mechanism whereby different neurotrophins influence the biology of medulloblastomas has not been elucidated.

Medulloblastomas are prototypical primitive neuroectodermal tumors (PNETs) that arise in cerebellum, and they are among the most common childhood brain neoplasms (Hart and Earle, 1973; Becker and Hinton, 1983; Rorke, 1983; Rorke et al., 1985; Peringa et al., 1995). Medulloblastomas resemble CNS neuroepithelial progenitor cells at the morphological level, although subsets of medulloblastomas express neuronal and/or glial markers (Tremblay et al., 1985; Molenaar et al., 1989; Gould et al., 1990). Medulloblastoma-derived cell lines that express markers of the 
neuronal lineage (e.g., D283MED) are thought to be more differentiated, whereas medulloblastoma cell lines that do not express markers of neuronal or glial lineage (e.g., DAOY) are thought to be more embryonal (Trojanowski et al., 1994; Peringa et al., 1995). Because no medulloblastoma cell lines express p75, we engineered one of these lines (i.e., D283MED or D283) to express human p75, but this cell line (known as A009 or D283p75) did not differentiate or cease dividing in response to treatment with exogenous NGF (Pleasure et al., 1990). Thus, we hypothesize that the TrkA receptor may be required to mediate responses to NGF in medulloblastoma cells. To test this hypothesis, we engineered the more differentiated D283 cells and the less differentiated DAOY cells to express TrkA on their cell surface by infecting these cells with a retrovirus harboring human $\operatorname{trk} A$ and then exposing these infected cells (D283trk and DAOYtrk cells) to exogenous NGF. Here, we show that D283trk and DAOYtrk cells respond to NGF by undergoing massive apoptosis.

\section{MATERIALS AND METHODS}

\section{Tissue culture, retroviral infection, and NGF treatment}

Uninfected D283MED (D283) and DAOY cells and cells infected with retrovirus were maintained with RPMI 1640 medium containing $10 \%$ fetal bovine serum and $2 \mathrm{~mm}$ glutamine (Friedman et al., 1985; Trojanowski et al., 1989). DAOY cells normally grow in a monolayer, whereas the D283 cells grow in suspension. Thus, for the MTS assays, fluorescence, and videomicroscopy as well as for the immunoblotting and immunostaining, monolayer cultures of the D283 cells were established by plating the cells onto poly-D-lysine- coated $(1 \mu \mathrm{g} / \mathrm{ml})$ tissue culture dishes or coverslips as described previously (Pleasure et al., 1990). For studies involving the use of serum-free medium, fetal bovine serum was omitted from the culture medium.

Retroviruses bearing a full-length human trk cDNA (trkAI isoform; Barker et al., 1993) cloned into the retroviral vectors (Miller and Rosman, 1989) pLNCX (designated as pLNCtrk; Stephens et al., 1994) and pLHDCX (designated as pLHDCtrk; Verdi et al., 1994) were packaged by electroporation in the GPenvamp12 packaging cell line (Markowitz et al., 1988). Supernatants containing the retroviruses were harvested and used directly to infect the medulloblastoma cell lines. After $16 \mathrm{hr}$ of infection, the viral supernatants were removed and the cells were incubated with media alone for an additional $24 \mathrm{hr}$ before selection with either G418 (World Precision Instruments, Sarasota, FL) at $0.8 \mathrm{mg} / \mathrm{ml}$ for the pLNCtrk construct or with L-histidinol (Sigma, St. Louis, MO) at 8 $\mathrm{mm}$ for the pLHDCtrk construct for an additional 3 weeks. The drugresistant D283 cells (designated as D283Ntrk and D283Htrk cells, respectively) were used either as a mass culture, or they were subcloned by limited dilution to obtain clonal lines that express high levels of trk $A$. Similar responses to NGF were obtained with the mass culture and the subclones of the D283Ntrk and the D283Htrk cells (data not shown). As controls, D283 cells were also infected with a retrovirus bearing the pLNCX empty retroviral vector (D283vec cells) or infected with a retrovirus containing human $\mathrm{p} 75$ (designated as D283p 75 cells: Pleasure et al., 1990 ) or with the pLNCtrkC construct. The pLNCtrk construct was also used to infect DAOY, PC12 ${ }^{\text {nnr5 }}$, and NIH-3T3 cells to generate a stable population of cells expressing the TrkA receptor. Additionally, the pLNCtrkC construct also was used to infect DAOY and D283 cells to generate stable populations of these cells that expressed the human TrkC receptor. Identical infection and selection procedures were used for all cell lines. Subclones of DAOYtrk cells and mass cultures of D283trk cells were used in the experiments presented here.

NIH-3T3 cells transfected with a rat trkAI cDNA (NIH-3T3trk designated here as 3T3trk cells; Mahadeo et al., 1994) and PC12 cells overexpressing TrkA (PC12-615 designated here as PC12trk, Hempstead et al., 1992) were used as positive controls for monitoring the expression of TrkA in the retrovirally infected medulloblastoma cells. Wild-type and transfected NIH-3T3 cells were maintained in DMEM supplemented with $10 \%$ calf serum, and penicillin/streptomycin. G418 $(0.2 \mathrm{mg} / \mathrm{ml})$ was added to the medium for continuous selection of 3T3trk cells. Wild-type PC12 and PC12trk cells were maintained as described (Hempstead et al., 1992).

NGF was extracted from mouse salivary glands according to previously published procedures (Mobley et al., 1976). Two other commercial sources of NGF were also used. Mouse NGF (2.5S) was obtained from Collaborative Biomedical Products (Bedford, MA), and human recombinant NGF- $\beta$ was obtained from Sigma. All NGF preparations were used to examine the biological effects of NGF on the wild-type and the genetically modified medulloblastoma cell lines (i.e., D283 and DAOY). The specificity of these effects was monitored by using a rabbit antibody to $2.5 \mathrm{~S}$ mouse NGF (Sigma) as well as a monoclonal antibody to recombinant NGF (Boehringer Mannheim, Indianapolis, IN) in blocking experiments. Recombinant NT3 was a gift from Regeneron (Tarrytown, NY).

Northern blots, immunoblots, and indirect immunofluorescence

Total RNA was extracted with Trizol (World Precision Instruments), and RNA $(25 \mu \mathrm{g})$ was then electrophoresed in a $1 \%$ agarose gel containing $2.2 \mathrm{M}$ formaldehyde, followed by transfer of the separated RNAs to a nylon membrane. After drying the membranes, the immobilized RNAs were probed with a full-length human trk $A$ cDNA probe labeled with $\left[{ }^{32} \mathrm{P}\right] \mathrm{dCTP}$ for $3 \mathrm{hr}$ and washed twice with $2 \times \mathrm{SSC}+0.1 \% \mathrm{SDS}$ at $42^{\circ} \mathrm{C}$, twice with $0.2 \times \mathrm{SSC}+0.1 \% \mathrm{SDS}$ at $42^{\circ} \mathrm{C}$, and once with $0.1 \times \mathrm{SSC}+$ $0.1 \%$ SDS at $55^{\circ} \mathrm{C}$. The labeled RNA species in these blots were visualized using a Phosphoimager and analyzed with ImageQuant software (Molecular Dynamics, Sunnyvale, CA).

The conditions for cell lysis and immunoblot analysis were exactly as described in earlier experiments with cells genetically engineered to express each of the major neurotrophin receptor proteins (Muragaki et al., 1995). For immunoblot analysis, cells were grown in poly-D-lysinecoated $10 \mathrm{~cm}$ dishes and harvested with Laemmli sample buffer, and the proteins denatured by boiling for $15 \mathrm{~min}$. Protein $(100 \mu \mathrm{g})$ was separated by SDS-PAGE (7.5\% polyacrylamide) gels and transferred onto nitrocellulose paper. The nitrocellulose replica was then divided into two portions using the $\mathrm{Mr}$ marker bovine serum albumin (i.e., $66 \mathrm{kDa}$ ) as a guide. The top part of the nitrocellulose replica was probed with E7, a previously described monoclonal antibody $(\mathrm{mAb})$ to the extracellular domain of TrkA (Muragaki et al., 1995), and the bottom part was probed with a $\mathrm{mAb}$ to $\alpha$-tubulin (Sigma). The relative amount of TrkA and $\alpha$-tubulin in each sample was revealed by enhanced chemiluminescence (ECL).

To detect the activated or autophosphorylated form of the TrkA receptor, D283trk cells were either untreated or treated with $100 \mathrm{ng} / \mathrm{ml}$ of NGF for 5 min. The cells were then lysed with cell lysis buffer (Trisbuffered saline containing 1\% SDS; 0.5 mM EDTA; 1 mM EGTA; and a cocktail of protease inhibitors including $1 \mathrm{mM}$ PMSF; $10 \mu \mathrm{g} / \mathrm{ml}$ aprotonin; $1 \mu \mathrm{g} / \mathrm{ml}$ each of leupeptin, TLCK, TPCK, and soybean trypsin inhibitors; and $0.5 \mathrm{~mm}$ sodium orthovanadate), sonicated on ice, and spun at $16,000 \times g$ for $30 \mathrm{~min}$. Then, $100 \mu \mathrm{g}$ of total protein from each cell lysate was separated on $10 \%$ SDS-PAGE gels, transferred onto a nitrocellulose replica, and probed first with a mouse anti-phosphotyrosine mAb (4G10, Upstate Biotechnology, Lake Placid, NY). After development of the nitrocellulose replica to reveal tyrosine phosphorylated proteins, the nitrocellulose replica was stripped with $1 \%$ SDS and reprobed with the $\mathrm{E} 7 \mathrm{mAb}$ and then redeveloped with ECL to identify the TrkA receptor in the same replica.

For indirect immunofluorescence experiments to detect cell surfaceexpressed Trk receptor protein, live (unfixed) wild-type and genetically modified medulloblastoma cells were incubated with a pan-trk mouse $\mathrm{mAb}$ (E13) specific for an epitope in the extracellular domain of Trk receptors (Muragaki et al., 1995) at $4^{\circ} \mathrm{C}$ for $90 \mathrm{~min}$. After washing to remove unbound antibodies, the cells were then fixed with $70 \%$ ethanol containing $150 \mathrm{~mm} \mathrm{NaCl}, \mathrm{pH} 7.0$, and a Texas red conjugated rabbit anti-mouse antibody was applied to these cells at room temperature for $60 \mathrm{~min}$ to reveal bound antibody.

To demonstrate that the NGF-induced cell death in D283trk and DAOYtrk cells requires tyrosine phosphorylation, the cells were pretreated with $100 \mathrm{nM}$ of K-252a (Kamiya Biochemical, Thousand Oaks, CA) for $1 \mathrm{hr}$ before the addition of NGF (Berg et al., 1992).

\section{Measurement of cell viability}

Cell viability was quantitated using the MTS (3-(4,5-dimethythiazol-2yl)-5-(3-carboxymethoxyphenyl)-2-(4-sufophenyl)-2H-tetrazolium, inner salt) assay according to procedures recommended by the vender (Promega, Madison, WI). To do this, $5 \times 10^{3}$ cells in serum-containing medium or $1 \times 10^{4}$ cells in serum-free medium were used to quantitate MTS in triplicate wells of 96 well-plates after incubating wild-type and genetically modified cells for $4 \mathrm{~d}$ in NGF as described above. The absorbence values at $450 \mathrm{~nm}$ were quantitated and compared with the values obtained from wells containing wild-type or genetically modified 
D283 cells that were not treated with NGF. Each MTS assay was repeated at least three times, and each experiment was done in triplicate. Furthermore, the results of the MTS assays correlated well with cell counts obtained using trypan blue exclusion assay.

\section{Measurements of apoptotic cell death}

Three complementary methods were used to monitor apoptotic cell death in NGF-treated TrkA expressing medulloblastoma cells.

Hoechst 33342 staining of apoptotic bodies. In this assay, cells were grown in suspension, incubated with $100 \mathrm{ng} / \mathrm{ml}$ of NGF for $4 \mathrm{~d}$, and stained with $5 \mu \mathrm{g} / \mathrm{ml}$ of the Hoechst 33342 dye for $5 \mathrm{~min}$ at room temperature. Normal nuclei and nuclear apoptotic bodies stained by the Hoechst 33342 dye were then visualized and monitored in each set of experiments by fluorescence microscopy.

Detection of DNA fragmentation induced by apoptosis. To detect DNA "laddering" in cells undergoing apoptosis, wild-type and genetically modified D283 cells were incubated with $100 \mathrm{ng} / \mathrm{ml}$ of NGF for $3 \mathrm{~d}$, and DNA from $\sim 8 \times 10^{6}$ cells was extracted as described (Tilly and Hsueh, 1993). The DNA was electrophoresed in $2 \%$ agarose gels, stained by $2 \mu \mathrm{g} / \mathrm{ml}$ ethidium bromide for $30 \mathrm{~min}$ at room temperature, and destained using distilled water at $4^{\circ} \mathrm{C}$ overnight. Alternatively, DNA "laddering" was detected in gels of similar DNA extracts by labeling the DNA fragments with $\alpha\left[{ }^{32} \mathrm{P}\right] \mathrm{ddATP}(30 \mu \mathrm{Ci})$ and $\mathrm{TdT}(25 \mathrm{U})$ at $37^{\circ} \mathrm{C}$ for $1 \mathrm{hr}$ before electrophoresis. In this procedure, unincorporated nucleotides were separated from the labeled DNA by precipitating the DNA twice with ethanol. These DNA samples were electrophoresed in $2 \%$ agarose gel, and the gel was denatured with $1.5 \mathrm{M} \mathrm{NaCl} / 0.5 \mathrm{M} \mathrm{NaOH}$ for $30 \mathrm{~min}$ followed by an extensive wash with $1.5 \mathrm{M} \mathrm{NaCl} / 1.0 \mathrm{M}$ Tris, $\mathrm{pH} 7.0$, for 30 min and transfer to a nylon membrane. These membranes were then analyzed with a Phosphoimager as described above.

Visualization of apoptosis by time-lapse videomicroscopy. Living wildtype and genetically modified D283 cells treated with NGF were monitored for evidence of apoptosis (e.g., membrane ruffling and blebbing, formation of apoptotic bodies) by videomicroscopy for up to $4 \mathrm{~d}$ during treatment with NGF as described (Pittman et al., 1993; Mills et al., 1995).

Flow cytometric analysis of apoptosis during different phases of the cell cycle

To monitor the occurrence of apoptosis during different phases of the cell cycle by flow cytometry, $\sim 2.5 \times 10^{6}$ of the D283trk cells were incubated with NGF for different lengths of time, stained with $50 \mu \mathrm{g} / \mathrm{ml}$ propidium iodide in hypotonic buffer containing $0.1 \%$ Triton $\mathrm{X}-100$ and $0.1 \%$ sodium citrate at $4^{\circ} \mathrm{C}$ overnight (Nicoletti et al., 1991), and analyzed with a FACScan (Becton-Dickinson Immunocytometry Systems, Mountain View, CA). The stained cells traversed the beam of light $(488 \mathrm{~nm}$ wavelength) emitted by an argon laser. A $560 \mathrm{~nm}$ dichroic mirror and a $585 \pm 21 \mathrm{~nm}$ bandpass filter were used for data collection. The forward scatter and side scatter of the red fluorescent particles (resulting from propidium iodide-stained DNA) were measured simultaneously with a threshold set up with FL2H 52. All of the data generated in these experiments were recorded with a Macintosh computer using CELL Quest research software (Becton-Dickinson Immunocytometry Systems) and ModFit software (Verity Software House) to analyze the number of cells in each phase of the cell cycle.

\section{RESULTS}

\section{Expression and autophosphorylation of TrkA receptors in D283trk and DAOYtrk cells}

To determine whether the wild-type D283 cells (which do not contain detectable p75) express any endogenous trk $A$, we performed Northern blot analysis on these and other genetically modified forms of the D283 cells using a full-length cDNA probe for human trk $A$. Figure $1 A$ shows that wild-type D283 cells as well as the D283vec (D283 cells infected with empty vector) and D283p75 cells do not express detectable trkA mRNA. Other experiments using primers corresponding to trk $A$ also failed to detect trk $A$ mRNA by RT-PCR. Furthermore, neither trkB nor trkC transcripts were detected in any of these cells by Northern blot analysis or RT-PCR (data not shown). However, D283 cells infected with retroviral constructs that were designed for selection with either neomycin (D283Ntrk) or L-histidinol (D283Htrk) demonstrated two distinct mRNA bands, and both bands were present at higher levels than the endogenous $\operatorname{trk} A$ transcripts in the rodent PC12 cells (Fig. $1 A$ ). The larger size of these trk $A$ bands in the D283Ntrk and D283HDtrk cells results from inclusion of the $5^{\prime}$ and $3^{\prime}$ long terminal repeats (LTRs), the packaging signal, the drug resistant gene, and the internal cytomegalovirus (CMV) promoter with the human trk $A$ coding sequences. The difference in the molecular weight of the upper bands in the D283Ntrk versus the D283Htrk cells probably reflects the fact that the length of the L-histidinol-resistant gene in the pLHDCX vector is $\sim 500$ bp larger than the neomycin-resistant gene in the pLNCX vector (Miller and Rosman, 1989). Notably, the expression level of the trkA transcripts in the D283Ntrk cells was slightly higher than in the 3T3trk cells, which were transfected with a construct harboring rat trkA (Mahadeo et al., 1994). Furthermore, in parallel experiments, we showed that the unmodified DAOY cell line did not contain any detectable endogenous $\operatorname{trk} A, \operatorname{trk} B$, or trkC transcripts, whereas trk $A$ mRNA was detected in the DAOYtrk cells (data not shown).

The expression of TrkA receptor proteins was monitored by Western blot analysis using E7, a mAb that recognizes an epitope in the extracellular domain of human TrkA (Fig. 1B). These studies showed that both the D283Ntrk and DAOYtrk cell lines exhibited two distinct TrkA immunoreactive bands of $\sim 125$ and $110 \mathrm{kDa}$. The poorly or nonglycosylated $110 \mathrm{kDa}$ TrkA band migrated similarly in the PC12trk, D283Ntrk, and DAOYtrk cells. However, the higher Mr $125 \mathrm{kDa}$ TrkA band in both D283Ntrk and DAOYtrk cells showed a more rapid electrophoretic mobility than the $140 \mathrm{kDa}$ TrkA band in the 3T3trk and PC12trk cells, which suggests that this NGF receptor may not be glycosylated as extensively in the D283Ntrk and the DAOYtrk cells as it is in the 3T3trk and PC12trk cells. It is evident that neither wild-type D283 nor DAOY contain detectable amounts of TrkA. Furthermore, the expression levels of TrkA in the D283trk cells were quite a bit lower than in the 3T3trk and PC12trk cells, whereas the expression levels of TrkA in DAOYtrk cells were comparable with those in the 3T3trk and PC12trk cells (Fig. 1B). Because the D283Ntrk cell line was used for all subsequent experiments, we refer to these cells as the D283trk cell line hereafter for simplicity. In addition, to confirm and extend the results obtained with the D283trk cells, we conducted selected studies on the DAOYtrk cells in parallel with those performed on the D283trk cell line, and representative data from these studies are reported below.

To determine whether TrkA was expressed on the plasma membrane of the D283trk cells, indirect immunofluorescence was performed on live D283trk cells using E13, a mAb that binds to an epitope in the extracellular domain of TrkA (Muragaki et al., 1995). These studies demonstrated that TrkA receptor proteins were expressed on the surface plasma membrane of the D283trk cells, whereas no immunoreactive TrkA was detected on the surface of the control D283vec cells (compare Fig. 2A, $a$ with $b$ ). Similarly, TrkA receptor proteins also were expressed on the cell surface of the DAOYtrk cells but not on wild-type DAOY cells (compare Fig. 2A, $c$ with $d$ ). To determine whether TrkA became activated after treatment of the D283trk cells with NGF, we monitored the ability of TrkA receptor proteins to undergo NGFinduced autophosphorylation on tyrosine residues. This was accomplished by treating the D283trk cells for 5 min with NGF followed by immunoblotting from cell lysates with an antiphosphotyrosine antibody. These studies showed that in the absence of NGF, there was little or no autophosphorylation of the TrkA receptors that were expressed in the D283trk cells (Fig. 2B). 


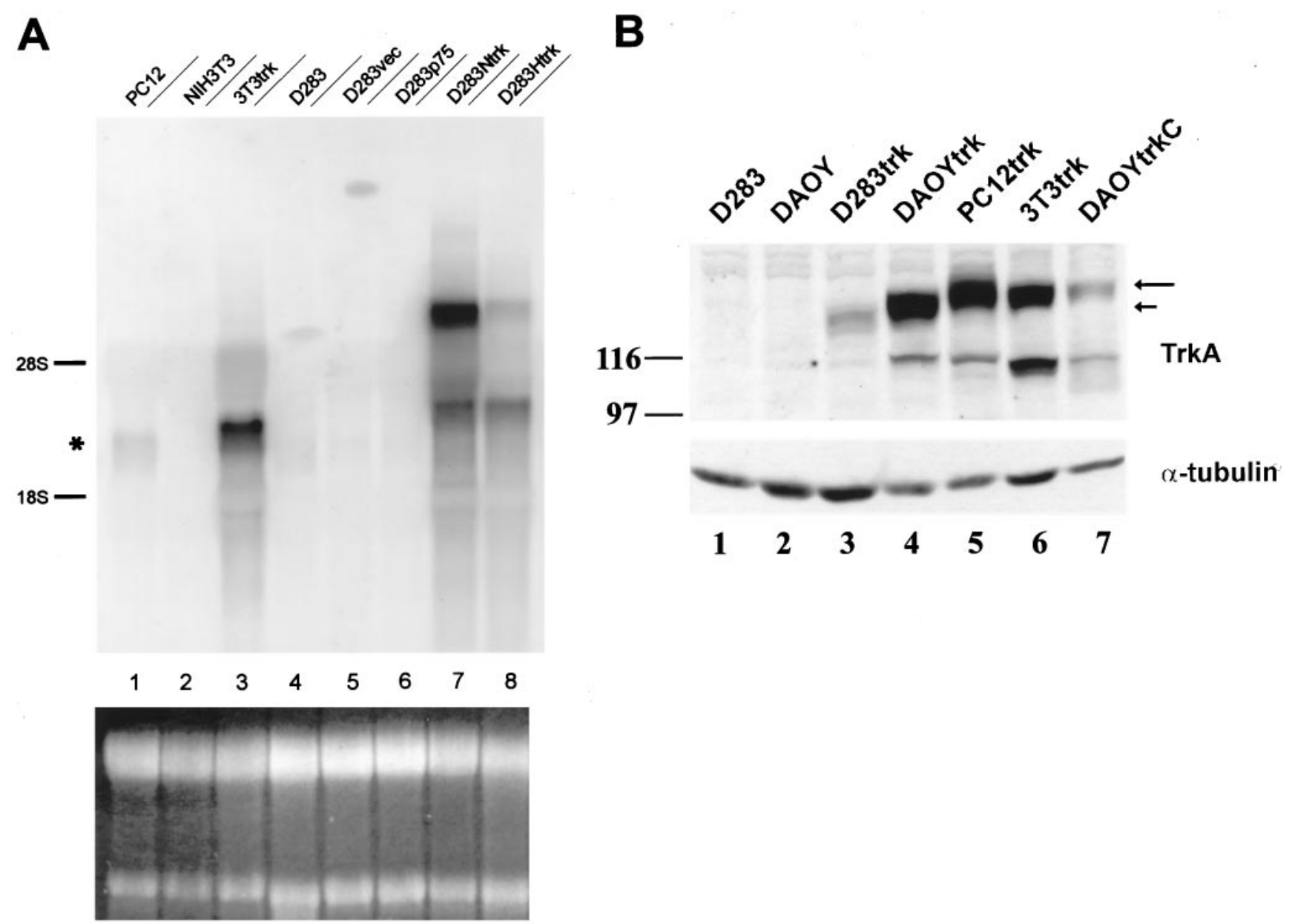

Figure 1. A, Expression of $\operatorname{trk} A$ transcripts in D283 cells infected with $\operatorname{trk} A$-containing retroviral vectors. Northern blots were performed on $25 \mu \mathrm{g}$ of total RNA from different cell lines following electrophoresis using cDNA probes to full-length human trk $A$. Notably, both the D283trk cells infected with pLNCtrk (D283Ntrk, lane 7) and with pLNHDtrk (D283Htrk, lane 8) retroviral vectors expressed high levels of trk $A$ transcripts. In contrast, no trk $A$ transcripts were seen in the parent D283 cells (lane 4), D283 cells infected with empty vector (D283vec, lane 5), or in the D283 cells infected with a retrovirus containing human $75^{\mathrm{LNGFR}}($ D283p 75 , lane 6$)$. Note that the rodent pheochromocytoma-derived PC12 cells express an $\sim 3.2 \mathrm{~kb}$ transcript corresponding to rat trk $A$ (asterisk). The two bands in D283trk cells correspond to trkA transcripts situated between the $5^{\prime}$ and $3^{\prime}$ LTRs of the retroviral vector (top bands) and between the internal CMV promoter and 3' LTR of this vector (bottom bands). The 28S and 18S molecular weight markers are shown to the left of lane 1 in the Northern blot, and the ethidium bromide-stained gel below demonstrates equal loading of the $28 \mathrm{~S}$ and $18 \mathrm{~S}$ ribosomal RNAs from the cell lines in each of the lanes shown above in the Northern blot. $B$, TrkA receptor protein expression in different cell lines engineered stably to express TrkA. Western blots were performed on cell extracts (100 $\mu \mathrm{g}$ of protein per lane) from each of the cell lines indicated above each lane in $B$ after electrophoresis in 7.5\% SDS-PAGE gels. TrkA was detected in blots probed with E7, a MAb directed against the extracellular domain of TrkA. The ascites was applied at a dilution of 1:1000. Both the D283trk (lane 3) and the DAOYtrk (lane 4) cell lines express $\sim 110$ and $\sim 125 \mathrm{kDa}($ short arrow) TrkA immunobands, both of which migrate more rapidly than the $140 \mathrm{kDa}$ (long arrow) species of fully glycosylated TrkA observed in the PC12trk (lane 5), 3T3trk cells (lane 6). Furthermore, trkC expressed in DAOYtrkC cells almost comigrated with TrkA bands from 3T3trk cells (compare lanes 6 and 7). No immunoreactive TrkA is seen in the wild-type D283 and DAOY cells (lane 1 and lane 2, respectively).

However, brief exposure of these cells to NGF induced autophosphorylation of tyrosine residues in TrkA. Finally, we confirmed that the immunoband detected by the anti-phosphotyrosine antibody was TrkA by stripping the nitrocellulose replicas and reprobing them with the E7 mAb, which detected the same TrkA immunoband in cell lysates prepared from NGF-treated or untreated cells (Fig. 2B).

\section{NGF induces cell death in medulloblastoma cells engineered to express TrkA}

To determine the nature of the biological response of the Trk expressing medulloblastoma cells to NGF, we treated similar aliquots of the different retrovirally infected medulloblastoma cells described above with NGF. The response of these cell lines to NGF was then monitored using a number of different comple- mentary assays of cell number and viability (Figs. 3-6). After a $3 \mathrm{~d}$ incubation with $100 \mathrm{ng} / \mathrm{ml}$ of NGF in complete culture medium (i.e., containing $10 \%$ fetal bovine serum), the wells plated with D283trk cells contained fewer cells than the wells containing the D283vec and D283p75 cells (compare Fig. 3, $a$ with $b, c$ with $d$, and $e$ with $f$ ). Similarly, the DAOYtrk cells also contained fewer cells after treatment with NGF (Fig. $3 g, h$ ). Furthermore, a large number of the D283trk and DAOYtrk cells were rounded up and floating, which suggested that they had undergone cell death. Notably, this effect of NGF was observed regardless of whether the D283trk cells were grown in suspension or in monolayer culture on poly-D-lysine-coated dishes. Additionally, a similar response to NGF was seen after stable infection of D283 cells with either the pLNCtrk or the pLHDCtrk vector as well as in sub- 


\section{A}

D283vec

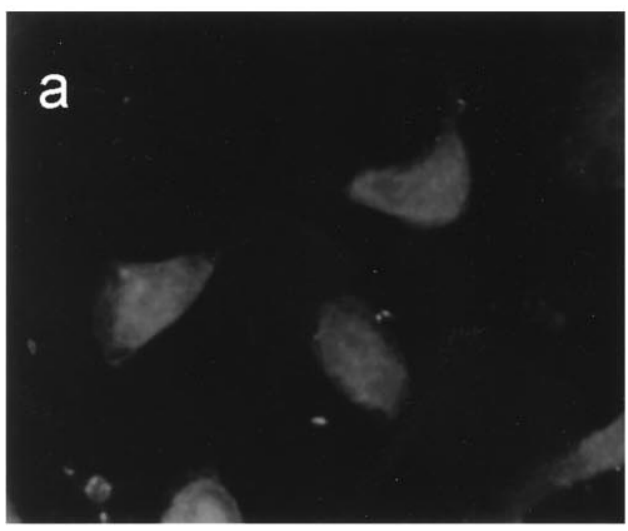

DAOY

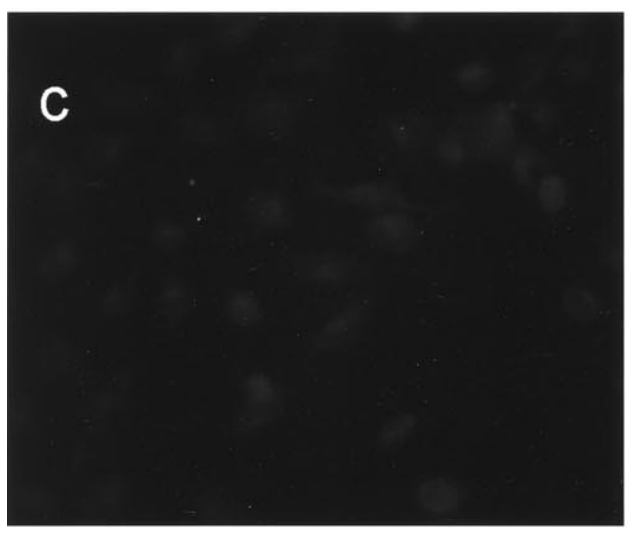

D283trk

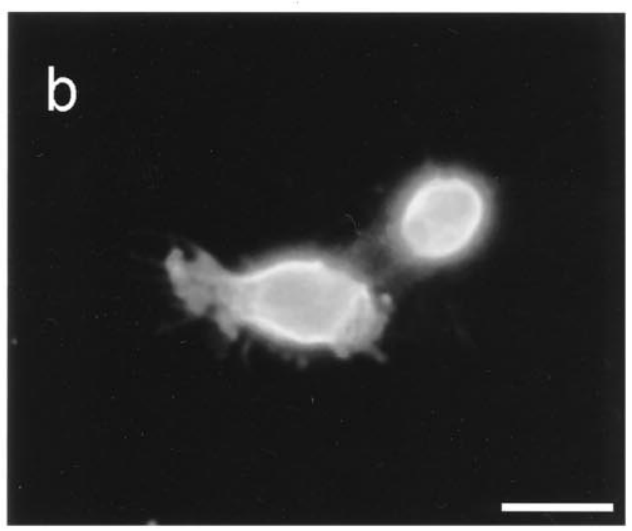

DAOYtrk

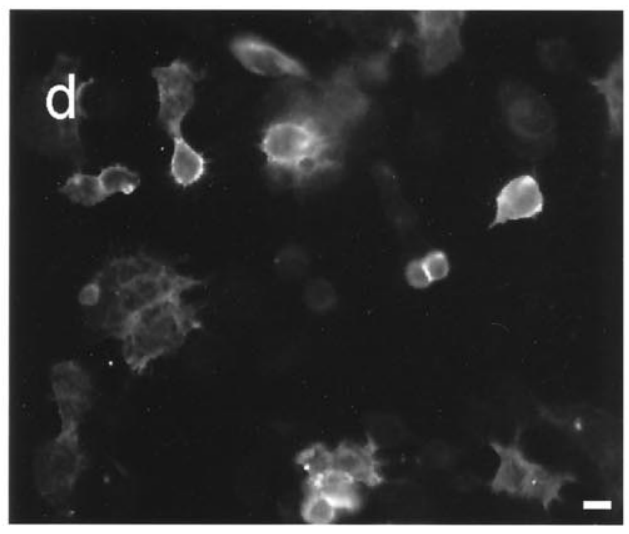

Figure 2. A, TrkA receptor protein expression on the cell surface of D283trk and DAOYtrk cells. Immunofluorescence images of D283vec (a), D283trk $(b)$ cells, uninfected DAOY $(c)$, and DAOYtrk $(d)$ after incubation with a mouse pan-trk antibody (E13) at $4^{\circ} \mathrm{C}$ for $90 \mathrm{~min}$ followed by fixation with $70 \%$ ETOH containing $150 \mathrm{~mm} \mathrm{NaCl}$ and a second incubation with a Texas red-conjugated rabbit anti-mouse IgM antibody for $1 \mathrm{hr}$. Scale bars, $20 \mu \mathrm{m}$. B, Autophosphorylation of the TrkA receptor after treatment of the D283trk cells with NGF. Gel electrophoresis (10\% SDS-PAGE) and Western blotting were performed on a cell lysate $(100 \mu \mathrm{g}$ of total proteins) from cells incubated with $100 \mathrm{ng} / \mathrm{ml}$ of NGF for 5 min. The nitrocellulose replica was probed with the anti-phosphotyrosine (4G10) mouse $\mathrm{mAb}$ and developed with ECL. After stripping the nitrocellulose replica with $1 \%$ SDS, the blot was reprobed with the E7 mAb to detect TrkA in the cell lysate. Note that an $\sim 125 \mathrm{kDa}$ immunoband corresponding to heavily glycosylated TrkA is the predominant species of TrkA recognized by the anti-phosphotyrosine $\mathrm{mAb}$ in the D283trk cells, but only after treatment of these cells with NGF. Duplicate lanes of D283trk cell lysates from NGFtreated and untreated cells were loaded.

clones of D283trk and DAOYtrk cells that expressed different levels of TrkA receptor protein (data not shown).

To demonstrate that the reduction in the number of D283trk and DAOYtrk cells was specific to NGF treatment, we conducted several sets of control experiments. First, we infected PC12 ${ }^{\mathrm{nnr} 5}$ (a PC12 mutant that does not express detectable TrkA and, therefore, does not respond to NGF) with the same $\operatorname{trk} A$ retroviral construct (i.e., pLNCtrk) and showed that these cells expressed functional TrkA receptors by extending long processes in response to treatment with NGF (data not shown). Second, because the NGF used in the experiments described above was prepared in our laboratory from extracts of salivary glands harvested from male mice, as described earlier (Mobley et al., 1976), we also used commercially available $2.5 \mathrm{~S}$ mouse NGF (Collaborative Research) and recombinant NGF (Sigma) to demonstrate that NGF from both commercial sources had similar effects on the D283trk 
-NGF
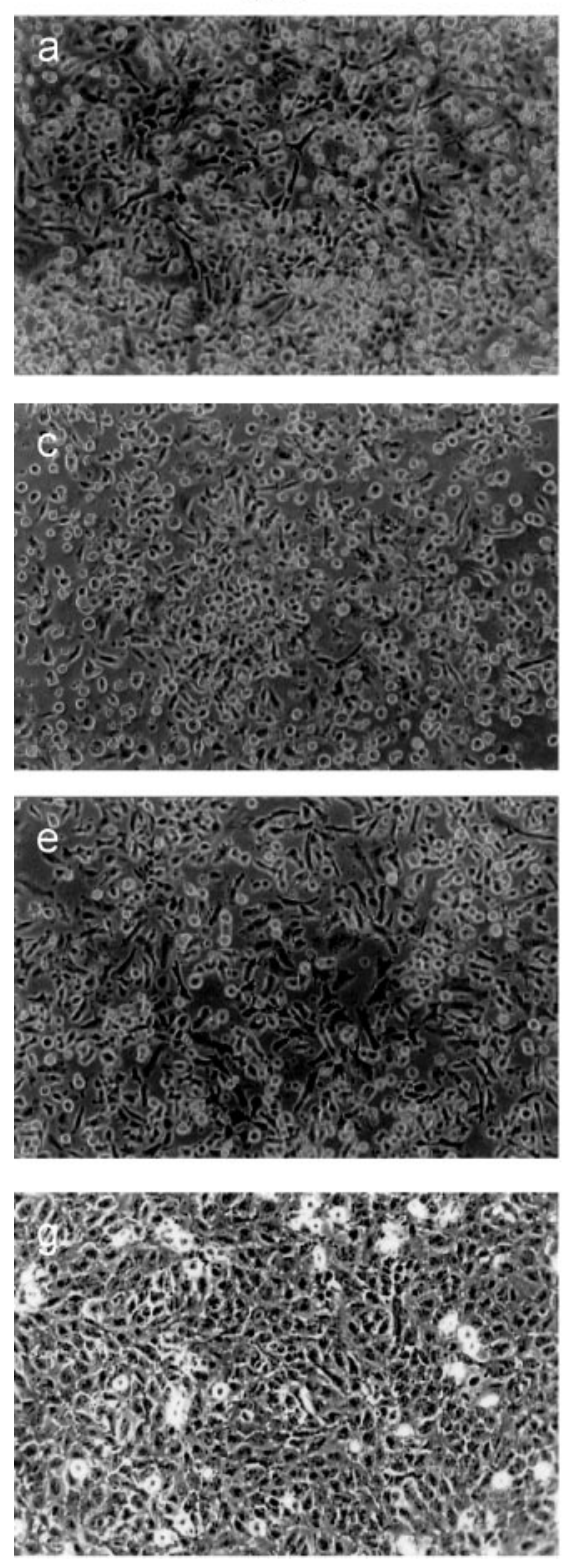

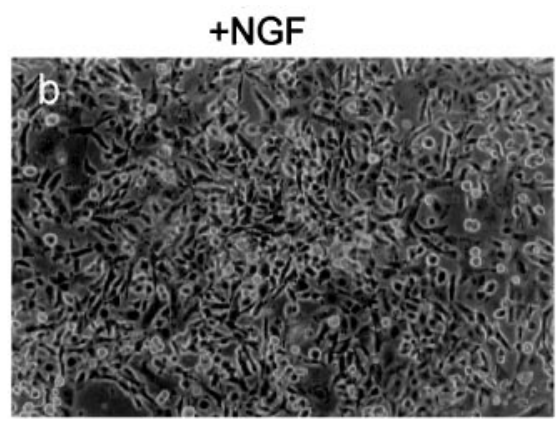

\section{D283vec}
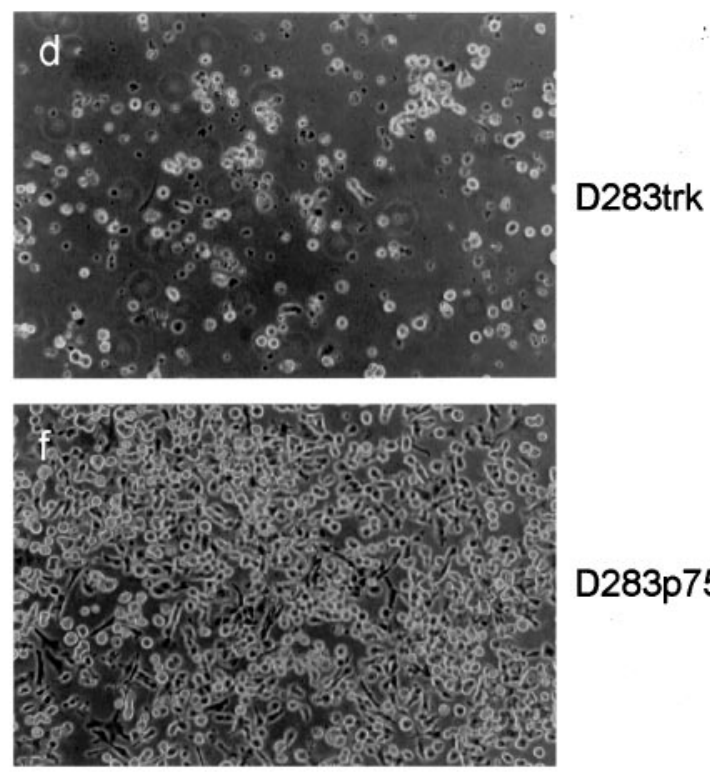

D283p75

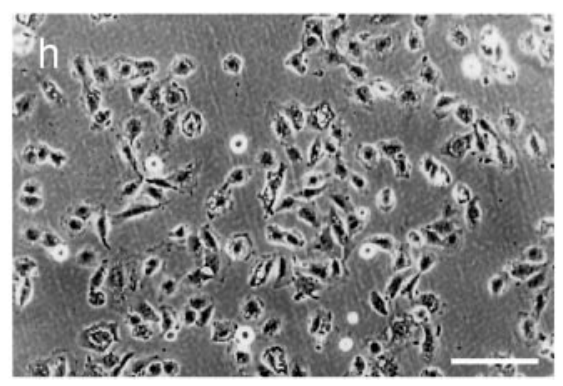

Figure 3. Response of retrovirusinfected D283 and DAOY cells to NGF. The images in this figure are phase-contrast photomicrographs of cells $\left(1.5 \times 10^{5}\right.$ per individual well of a 24 well-plate) that were grown with $(+N G F)$ or without $(-N G F)$ exposure to $100 \mathrm{ng} / \mathrm{ml} \mathrm{NGF}$ for $3 \mathrm{~d}$. Whereas untreated D283trk and DAOYtrk cells continue to divide, NGF-treated cells showed a decrease in cell number (compare $c$ with $d, g$ with $h$ ). D283 cells that were infected with vector alone (D283vec in $a$ and $b$ ) or infected with retrovirus to express p75 (D283p75 in $e$ and $f$ ) continued to divide and showed no evidence of cell death in response to treatment with NGF. Scale bars (shown in $h): 200 \mu \mathrm{m}$. and DAOYtrk cells (data not shown). A third control was performed by adding an anti-NGF antibody to the culture medium, which blocked the effects of NGF treatment on the D283trk cells in a dose-dependent manner. For example, at an antibody dilution of $\leq 1: 500$ of a polyclonal antisera, anti-NGF antibody completely blocked the effects of NGF on the D283trk cells (compare Fig. 4, $a$ with $b$ ). Similar effects also were observed using a mAb to NGF (data not shown). Fourth, pretreatment of D283trk and DAOYtrk cells with K-252a, a specific blocker of TrkA tyrosine phosphorylation (Berg et al., 1992), completely blocked the induction of cell death by NGF (Fig. $4 c, d$ ). Fifth, additional controls were performed using NT3 (i.e., the neurotrophin that is the cognate ligand for the TrkC receptor), because NT3 also binds weakly to TrkA receptors (Cordon-Cardo et al., 1991; Ip et al., 1993; Clary and Reichardt, 1994). These experiments showed that treatment of the D283trk and DAOYtrk cells with $100 \mathrm{ng} / \mathrm{ml} \mathrm{NT3}$ only had a small effect on the number of D283trk and DAOYtrk cells. However, at $1 \mu \mathrm{g} / \mathrm{ml}$ and higher concentrations, NT3 also induced cell death in TrkA expressing D283 and DAOY cells (compare Fig. 4, $e$ with $f$ ). Finally, as additional controls, we treated D283 and DAOY cells that were engineered to stably express the TrkC receptor with NT3, but this did not augment or enhance the death of cells in either of these cell lines (Fig. $4 g, h$ ). Thus, this set of experiments provides additional evidence indicating that the effects of NGF treatment on the number of TrkA-expressing medulloblastoma cells is specific to NGF.

To quantify the reduction in the number of NGF-treated D283trk cells, we monitored the viability of D283trk cells using the MTS assay that was performed on cells treated with different concentrations of NGF. These experiments were conducted after standard curves for the MTS assay were established to document a linear relationship between the number of D283trk cells and the absorbence values of MTS at $450 \mathrm{~nm}$. After treatment of the D283trk cells with NGF for $4 \mathrm{~d}$ in complete medium, the MTS assay confirmed that there was a dramatic reduction in the number of viable D283trk cells (Fig. $5 A$ ). Moreover, an inverse dose- 


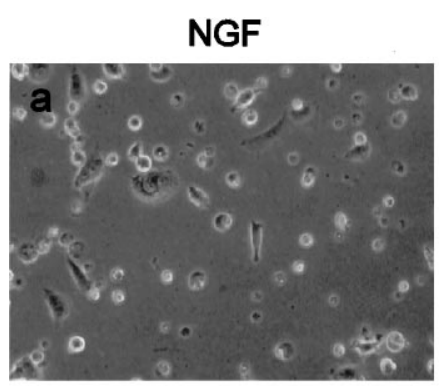
number induced by NGF in D283trk cells was blocked with the anti-NGF antibody (designated here $\alpha N G F$ and used at a dilution of 1:500) as evidenced by comparing the images in $a(+N G F)$ and $b(+N G F+\alpha N G F) . c, d \mathrm{~K}-252 \mathrm{a}$ (which inhibits tyrosine phosphorylation of TrkA) inhibits NGFinduced cell death in DAOYtrk cells. $e, f$, NT3 at $1 \mu \mathrm{g} / \mathrm{ml}$ also induces cell death in DAOYtrk cells. $g, h$, The treatment of DAOY cells stably expressing the TrkC receptor with NT3 did not result in cell death. Note that the expression of TrkC, but not TrkA, resulted in a dramatic alteration in the morphology of DAOY cells. Scale bars (shown in $h): 200 \mu \mathrm{m}$.

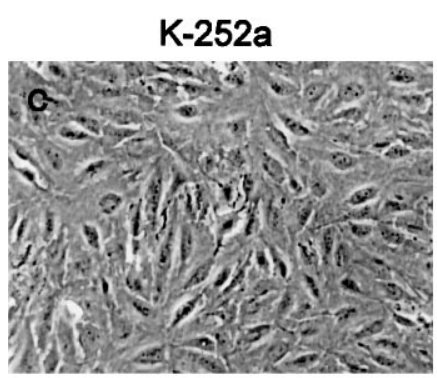

$100 \mathrm{ng} / \mathrm{ml} \mathrm{NT-3}$

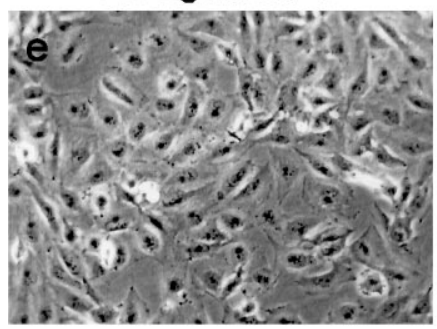

- NT-3
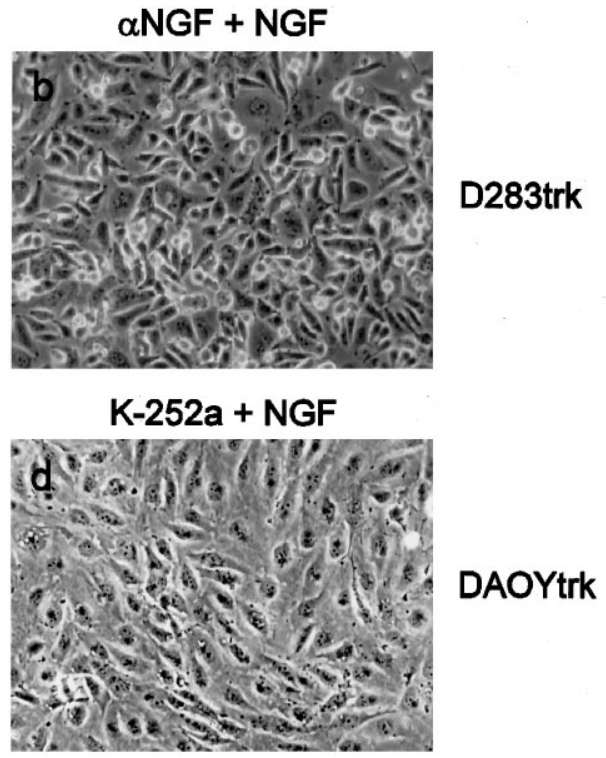

DAOYtrk

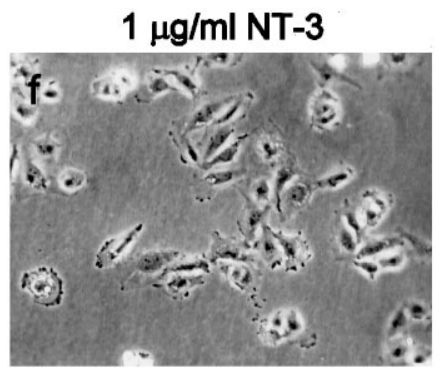

DAOYtrk
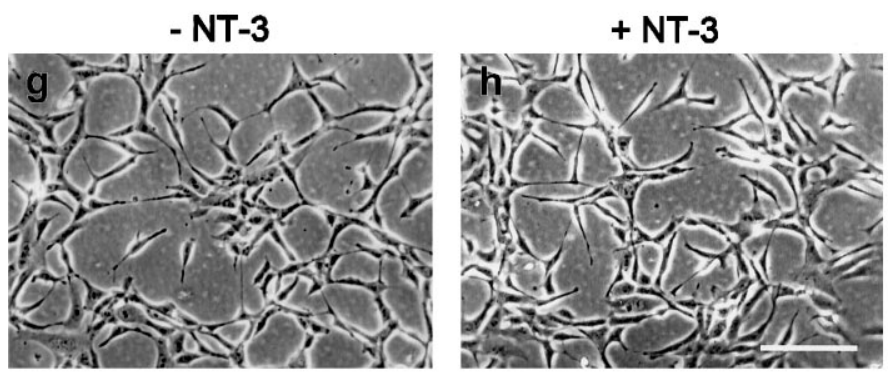

DAOYtrkC dependent relationship was seen between the concentration of NGF and the number of remaining D283trk cells. Because $50 \%$ of the D283trk cells were eliminated by treatment of these cells with $1-5 \mathrm{ng} / \mathrm{ml} \mathrm{NGF}$, it is likely that this effect of NGF is mediated by the high-affinity TrkA receptors. This interpretation was supported by parallel studies of the D283vec and D283p75 cell lines, because neither of these cell lines showed any significant reduction in cell viability (as monitored by the MTS assay) after treatment with NGF (Fig. 5A). To determine whether serum was required for the induction of cell death in the D283trk cells by treatment with NGF, we also performed the MTS assay on cells cultured in serum-free medium (Fig. $5 B$ ). In these experiments, NGF caused a $51 \%$ reduction in the viability of the D283trk cells at $100 \mathrm{ng} / \mathrm{ml}$ compared with D283trk cells that were not treated with NGF. Although the D283vec cells did not show any changes in their response to treatment with NGF under similar conditions, NGF treatment did have a mild effect on the viability of the D283p75 cells, and this effect was significant after treatment with $10 \mathrm{ng} / \mathrm{ml}$ NGF (Fig. 5B). Taken together, these findings demonstrate that NGF selectively compromises the viability of D283trk cells and that the ability of NGF to induce cell death in the D283trk cells is independent of the presence or absence of fetal bovine serum in the culture medium.

\section{NGF-induced cell death in D283trk and DAOYtrk cells exhibits hallmarks of apoptosis}

To characterize the type of cell death induced by NGF in the D283trk cells, we used three different complementary strategies:

(1) fluorescence microscopy and staining with Hoechst 33342 dye, (2) gel electrophoresis to detect DNA fragmentation, and (3) time-lapse videomicroscopy. In addition, NGF-treated DAOYtrk cells also were stained with Hoechst 33342 dye and examined by fluorescence microscopy to determine whether they also showed morphological evidence of apoptosis.

Immunofluorescence studies performed on cells stained with the Hoechst 33342 dye revealed condensation and fragmentation of the nuclear chromatin in numerous D283trk cells treated with NGF for $4 \mathrm{~d}$, whereas similar nuclear changes were extremely rare or absent in untreated D283trk cells as well as in the NGF-treated D283vec cells (Fig. 6 $A, a-c$ ). Similarly, when DAOYtrk cells were 

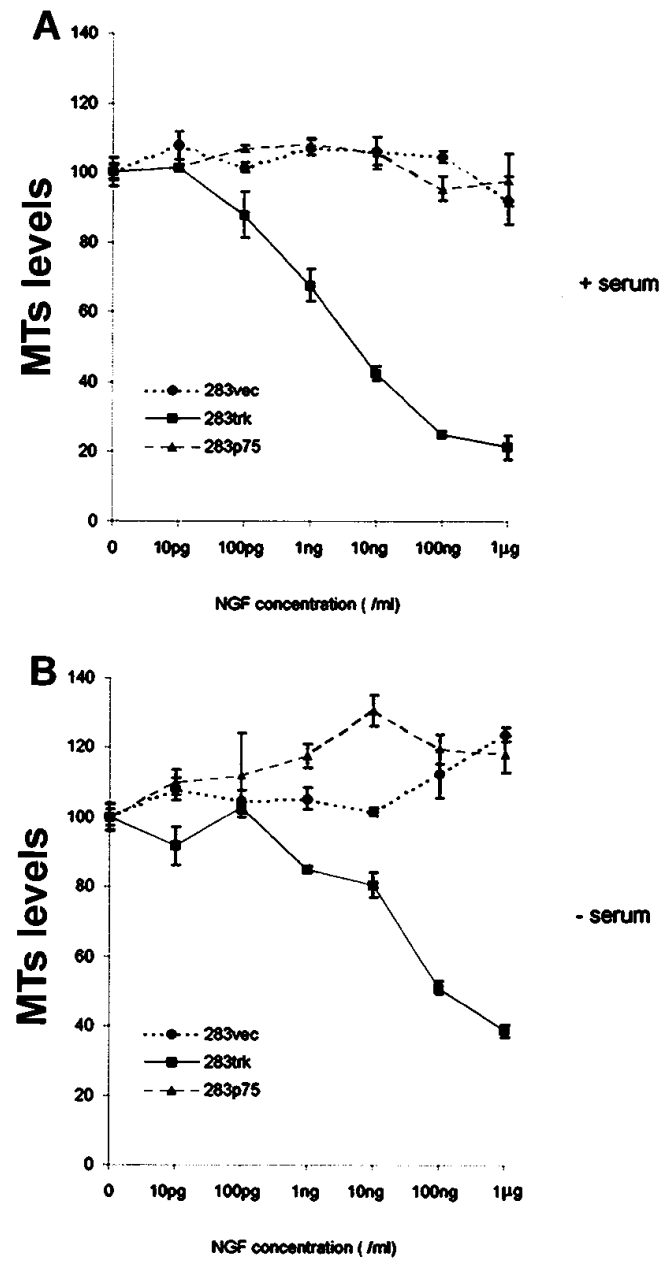

Figure 5. Dose response to and effect on viability of retrovirus-infected D283trk cells after treatment with NGF. Cells $\left(5 \times 10^{3}\right.$ cells grown in the presence of serum, and $1 \times 10^{4}$ cells grown in the absence of serum) were incubated with different concentrations of NGF in three independent wells of a 96 well-plate for $4 \mathrm{~d}$. Increasing concentrations of NGF were administered as shown on the $x$-axis of the graphs in $A$ and $B$. The viability of the D283trk cells was examined using the MTS assay, and the MTS levels for the cells in the wells without NGF were assigned a value of $100 \%$. In the presence of serum $(A), \mathrm{D} 283$ trk (solid squares with solid lines) showed a clear decrease of cell viability in a dose-dependent manner, whereas the D283vec (solid circles with dotted lines) and the D283p75 (shaded triangles with dashed lines) cells did not evidence diminished viability even after treatment with $1 \mu \mathrm{g} / \mathrm{ml}$ NGF. Qualitatively similar results were seen when cells were not grown in the absence of serum $(B)$.

treated with NGF for $2 \mathrm{~d}$ and then stained with the Hoechst dye, they also revealed condensation and fragmentation of their nuclear chromatin (compare Fig. $6 A, d$ with $e$ ). These findings are consistent with an apoptotic form of cell death in both of these cell lines, and DNA gel electrophoresis supported this interpretation because treatment of the D283trk cells with NGF induced a DNA "ladder" characterized by DNA fragments of multiples of $180 \mathrm{bp}$ (Fig. 6B). To further analyze and quantify the extent of DNA fragmentation in the NGF-treated D283trk cells, we used a 3' end-labeling method to tag DNA fragments with $\left[{ }^{32} \mathrm{P}\right] \mathrm{ddATP}$ at different times after treatment of the D283trk cells with NGF. These studies revealed a DNA "ladder" indicative of apoptosis as early as $24 \mathrm{hr}$ after treatment of the D283trk cells with NGF, and the intensity of the DNA "ladder" increased even further after 48 and $72 \mathrm{hr}$ of treatment (Fig. 6C).
Because videomicroscopy enables prolonged in vitro observations of individual cells after experimental manipulation, we examined the D283trk cells by this method after NGF treatment. These videomicroscopy studies showed that many of the NGFtreated D283trk cells became spherical at $12 \mathrm{hr}$, followed by membrane ruffling and blebbing during the next 24-72 hr (Fig. 7). For example, Figure 7 illustrates representative serial changes in one of the NGF-treated D283trk cells during late stages of apoptosis, including the typical membrane blebbing associated with apoptosis followed by a loss of cell volume and disintegration of the cell. Because these morphological features are associated with active apoptosis (Deckwerth and Johnson, 1993; Pittman et al., 1993; Schiffer et al., 1994; Mills et al., 1995), the videomicroscopy observations provide additional evidence that NGF induces an apoptotic form of cell death in the D283trk cells. Most of the D283trk cells monitored by videomicroscopy died after treatment with NGF for $4 \mathrm{~d}$, and many of these cells exhibited the morphological features of apoptosis described above and illustrated in Figure 7.

\section{NGF-induced apoptosis in the D283trk cell line is cell cycle-dependent}

Flow cytometric analysis was performed on NGF-treated D283trk cells to determine whether NGF induced apoptosis in a cell cycle-dependent manner. NGF treatment resulted in an $\sim 70 \%$ decrease in the percentage of D283trk cells in the $S$ phase of the cell cycle at $24 \mathrm{hr}$ after treatment, with a more modest decrease in the number of these cells in the G0/G1 and G2/M phases of the cell cycle (Fig. $8 A-C$ ). Although the percentage of D283trk cells in $\mathrm{G} 0 / \mathrm{G} 1$ and $\mathrm{G} 2 / \mathrm{M}$ gradually decreased further with time (Fig. $8 A-C$ ), these studies demonstrate an early vulnerability of the $\mathrm{S}$ phase D283trk cells to apoptosis after treatment with NGF. The quantitative analysis of the absolute number of NGF-treated D283trk cells in each phase of the cell cycle demonstrated a similar preferential loss of S phase D283trk cells. For example, the number of D283trk cells in S phase promptly decreased by $70 \%$ within the first $24 \mathrm{hr}$ of NGF treatment, whereas cells in the G2/M phase decreased much more gradually, i.e., by $46 \%$ after $96 \mathrm{hr}$ of treatment with NGF.

\section{DISCUSSION}

The series of studies described here provide the first compelling evidence that NGF can act through the TrkA receptor to induce an apoptotic form of cell death in authentic human brain tumorderived cell lines. Although histochemical evidence of apoptosis has been observed in biopsy samples of human medulloblastomas (Schiffer et al., 1994), this is the first study to demonstrate directly that NGF specifically induces apoptosis in two human medulloblastoma-derived cell lines by activating its cognate highaffinity receptor, i.e., TrkA. Although NGF and other neurotrophins (i.e., BDNF, NT3, NT4/5, NT6) are known to have pleiotrophic effects on different cell types, these factors are primarily known for their ability to promote the proliferation, survival, and maturation of target cells, whereas cell death is generally thought to be a consequence of neurotrophin withdrawal rather than the exposure of cells to one of these factors (Deckwerth and Johnson, 1993; Pittman et al., 1993; Freeman et al., 1994; Barbacid, 1995; Mills et al., 1995). In addition, although each of the major neurotrophin receptors (including p75) as well as several neurotrophic factors have been detected in biopsy samples of human medulloblastomas (Baker et al., 1991; Segal et al., 1994; Washiyama et al., 1996) and preliminary studies of medulloblastoma 
A
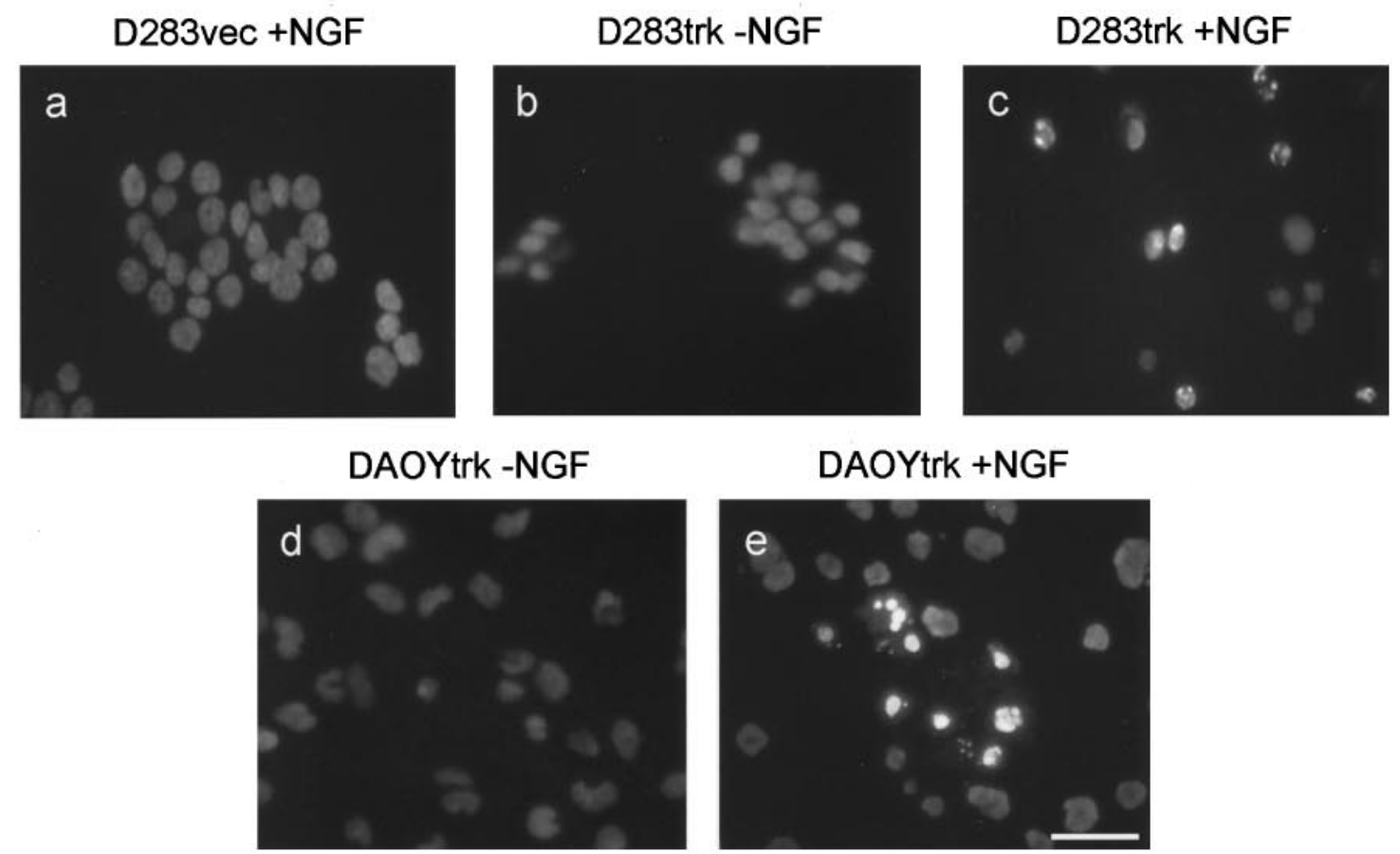

B
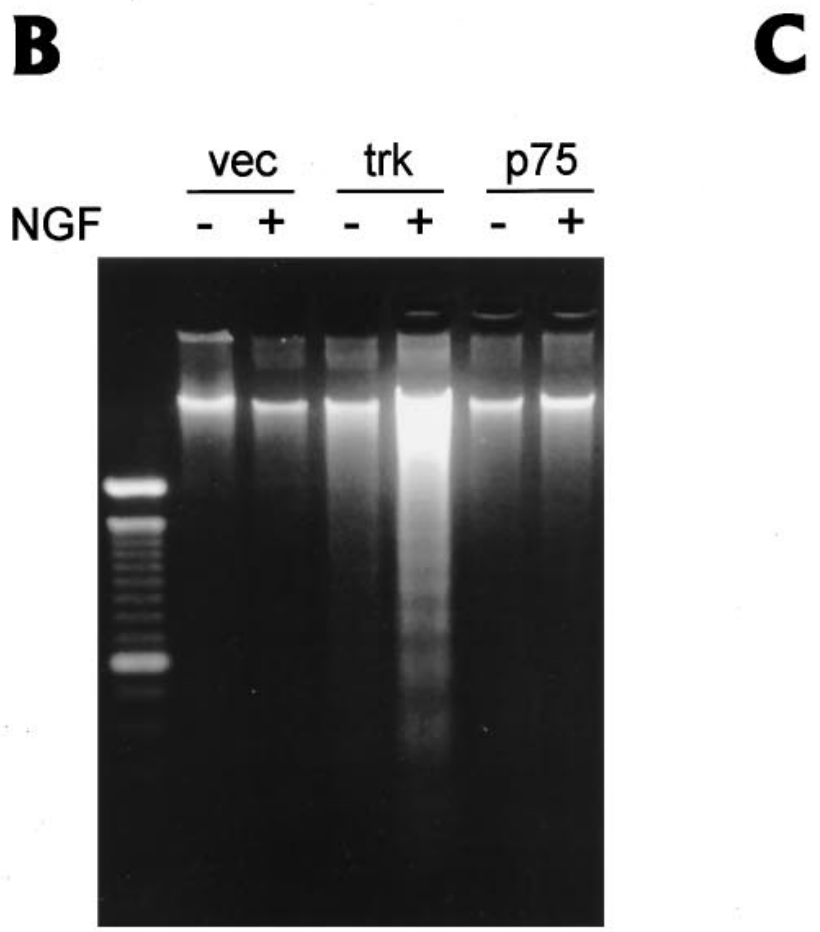

$\begin{array}{llllll}1 & 2 & 3 & 4 & 5 & 6\end{array}$
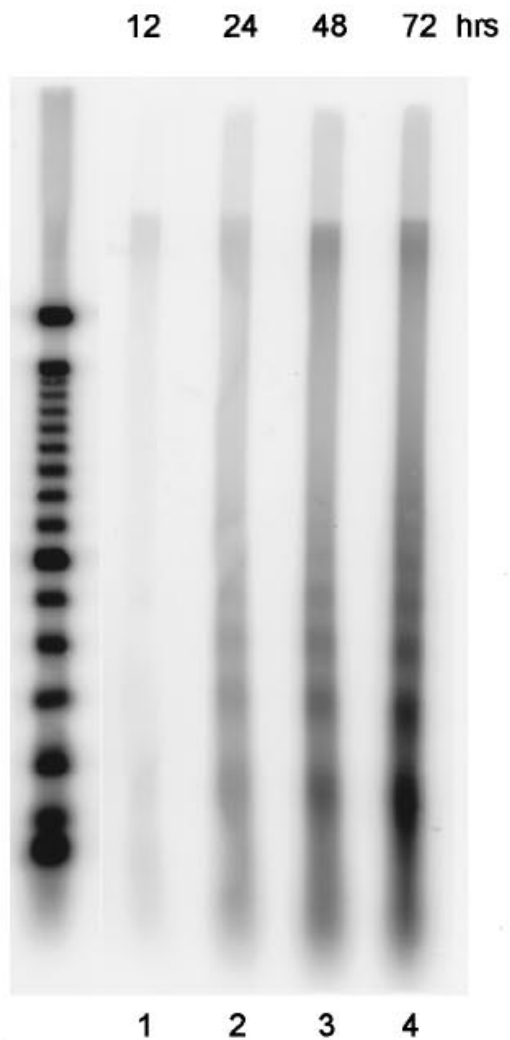

Figure 6. A, Morphological evidence of apoptotic death in D283trk and DAOYtrk cells induced by treatment with NGF for 4 and 2 d, respectively. Hoechst 33342 staining did not demonstrate the formation of condensed chromatin in the D283vec cells treated with NGF (D283vec $+N G F$ in $a$ ) or in the D283trk and DAOYtrk cells in the absence of NGF ( $b$ and $d$, respectively). However, condensed chromatin was seen in (Figure legend continues) 

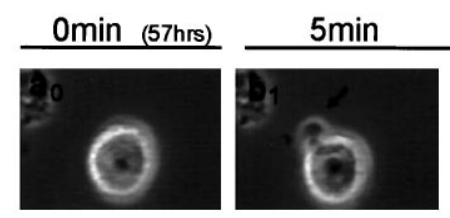

$6 \mathrm{~min}$ $7 \mathrm{~min}$ $8 \mathrm{~min}$

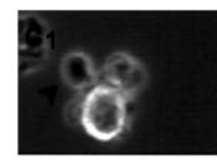

$27 \mathrm{~min}$

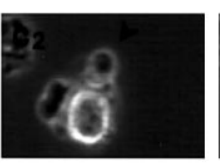

$28 \mathrm{~min}$
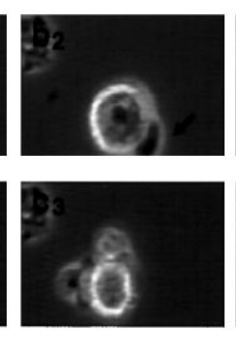

$29 \min$

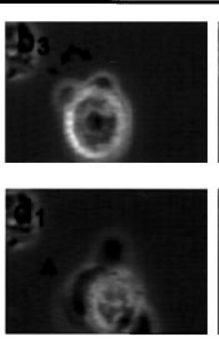

$46 \mathrm{~min}$
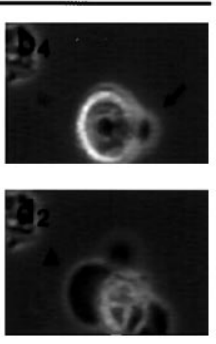

$48 \mathrm{~min}$
Figure 7. Time-lapse videomicroscopy of apoptotic cell death in the D283trk cells after treatment with NGF. Cells $\left(5 \times 10^{5}\right)$ were plated on $35 \mathrm{~mm}$ coverglasses coated with $1 \mu \mathrm{g} / \mathrm{ml}$ poly-D-lysine and observed by time-lapse videomicroscopy to monitor cell death events at the times indicated in each image. Apoptosis was common, and a cell that died an apoptotic death beginning at $\sim 57 \mathrm{hr}$ after NGF treatment is followed at subsequent time intervals from 0 to $48 \mathrm{~min}$ in the images in a0 through $\mathrm{d} 2$. Initially, this cell appeared normal $(a 0)$, but typical blebs (arrows in $b 1$ through $b 4$ ) begin to develop in the NGF-treated D283trk cells. Approximately $30 \mathrm{~min}$ before the death of this cell, a number of apoptotic bodies can be observed. Finally, more massive blebs develop (triangles in $d 1$ and $d 2)$, and the cell body begins to disintegrate $(d 2)$. biopsies suggest that the levels of trkC mRNA correlate with a better response to therapy (Segal et al., 1994), it is unclear what effects NGF or other neurotrophins have on the biology of these or other human brain tumors. Hence, the studies described here have important implications for understanding the function of NGF and TrkA in the developing normal nervous system as well as in human brain tumors

To elucidate the role of NGF and TrkA in the pathobiology of medulloblastomas, we generated the D283trk and DAOYtrk cells. We demonstrated that these cells expressed functional TrkA receptors on their plasma membranes, as evidenced by the ability of the TrkA receptors to undergo autophosphorylation at specific tyrosine residues in response to treatment with NGF. We then showed that NGF selectively and specifically induced an apoptotic form of cell death in the D283trk and DAOYtrk cells by using several different measures of cell viability and by applying several different morphological, histochemical, and biochemical criteria for the recognition of apoptosis including the presence of apoptotic bodies, blebbing of the cell membrane, the condensation and fragmentation of nuclear chromatin, and DNA laddering. Additionally, we confirmed that this apoptotic cell death response to NGF treatment was independent of factors present in serum, because NGF-treated D283trk cells underwent apoptosis when grown in either serum-containing or serum-free medium. Furthermore, we also presented data to suggest that NGFinduced apoptosis in the D283trk and DAOYtrk cells was mediated by the TrkA receptor. For example, D283 cells, engineered to express p75 (D283p75 cells), did not undergo apoptosis in response to NGF (Pleasure et al., 1990), and the half-maximal response of the D283trk cells to NGF only required $1-5 \mathrm{ng} / \mathrm{ml} \mathrm{NGF}$, which is indicative of high-affinity ligand/receptor binding. Additionally, several batches of mass cultures or clonally derived D283trk and DAOYtrk cells stably expressing varying levels of TrkA protein responded similarly to NGF. Other evidence also supports the notion that the induction of cell death in D283trk cells is specific to NGF, because NGF-induced apoptosis was blocked by both polyclonal and $\mathrm{mAb}$ to NGF, and at least two different preparations of NGF (including recombinant NGF) induced apoptosis in these cells. Notably, another member of the neurotrophin family that binds very weakly to the TrkA receptor (i.e., NT3) induced apoptosis in the D283trk and DAOYtrk cells but only at high concentrations. Furthermore, K-252a (a specific inhibitor of TrkA tyrosine phosphorylation) completely blocked the effects of NGF. Finally, we also showed that NGF-induced apoptosis is specific to NGF and TrkA, because treatment of D283 and DAOY infected by the same retroviral vector bearing the TrkC receptors with NT3 did not result in cell death. Although the studies summarized here provide compelling evidence that apoptosis is a consequence of the activation of NGF/ TrkA signaling pathways, the induction of apoptosis in response to NGF treatment via the TrkA receptor is cell type-specific, because the expression of TrkA receptors in both the NIH-3T3 and PC12 ${ }^{\text {nnr5 }}$ cells using the same retroviral vector system did not lead to apoptosis after treatment of these cells with NGF.

Although the precise intracellular signaling mechanisms that account for the findings reported here are unknown, NGF has a number of well-documented but diverse biological effects. For example, NGF enhances the survival and differentiation of a variety of PNS and CNS neurons including sympathetic, sensory, and cholinergic neurons (Levi-Montalcini and Angeletti, 1968; Mobley et al., 1989; Lindsay et al., 1994). Furthermore, NGF also promotes the differentiation and proliferation of neural progenitor cells such as chromaffin precursor cells and neuroepithelial stem cells (Unsicker et al., 1978; Doupe et al., 1985; Lillian and Claude, 1985; Cattaneo and McKay, 1990). However, a recent study shows that during early development, endogenous NGF can cause the death of retinal neurons that express p $75^{\text {LNGFR }}$ but not TrkA (Frade et al., 1996). Thus, these studies provide evidence that NGF can enhance normal developmentally regulated programmed cell death in vivo via interactions with $\mathrm{p} 75^{\text {LNGFR }}$. Our studies suggest that $\mathrm{p} 75^{\text {LNGFR }}$ may not be the only neurotrophin receptor involved in NGF-mediated cell death, because NGF induced apoptosis selectively in D283trk cells but not in D283p75 cells.

Several distinct signal transduction pathways are known to mediate the biological effects of NGF, including differentiation and cell survival (Thomas et al., 1992; Wood et al., 1992; Kaplan et al., 1994; Stephens et al., 1994; Yao and Cooper, 1995). For example, one of the consequences of NGF/TrkA signaling is the

$\leftarrow$

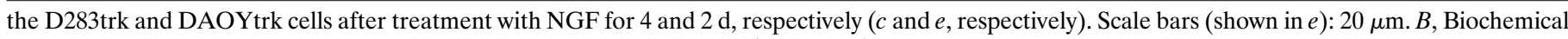

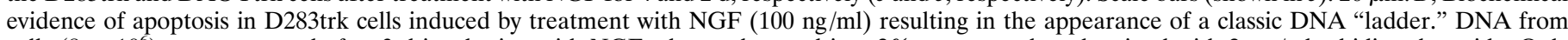

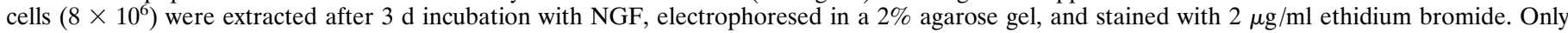

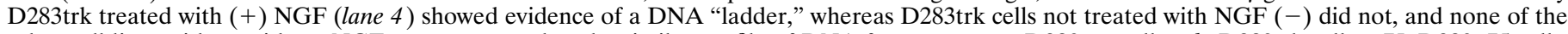

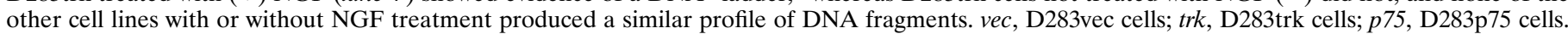

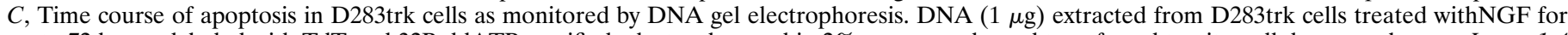

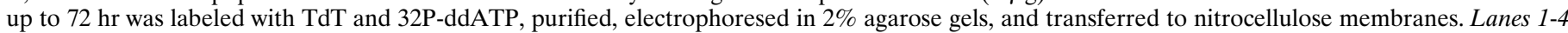

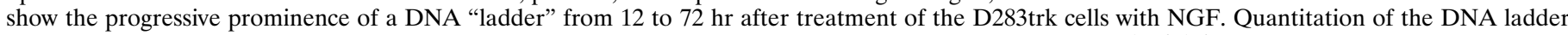
showed an exponentially increasing signal intensity after $24 \mathrm{hr}$. Molecular weight markers are shown in the far left lane. 
A
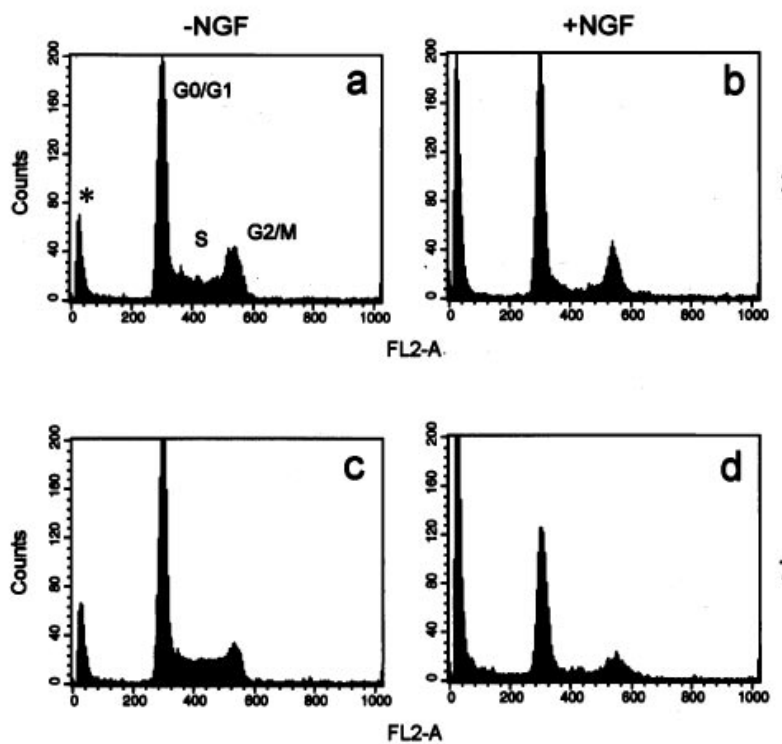

B
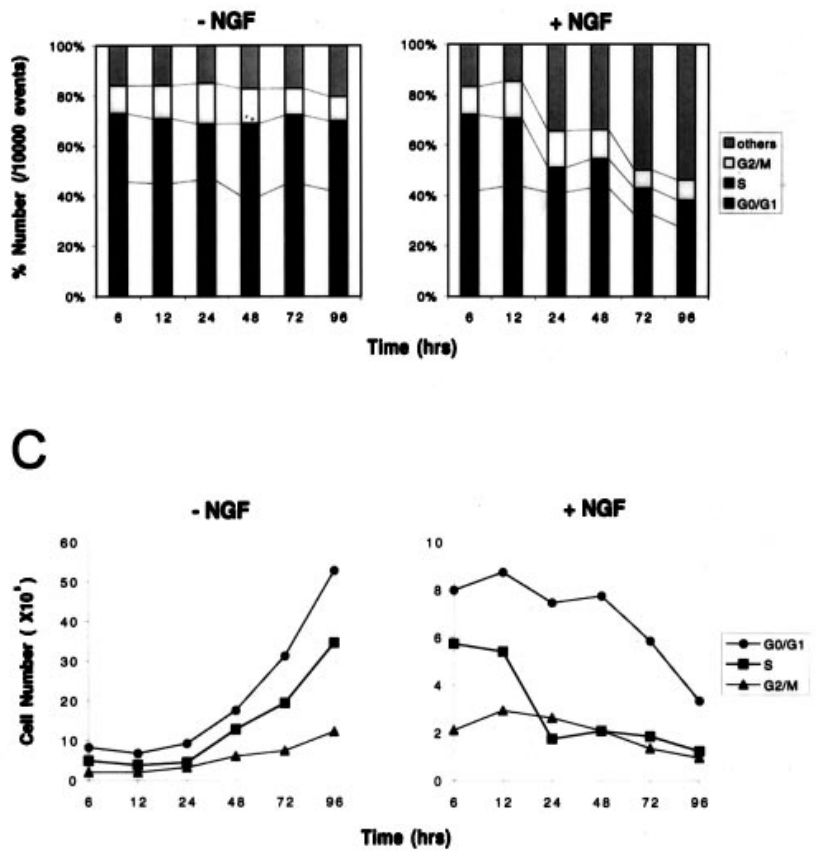

Figure 8. Loss of populations of D283trk cells at different stages of the cell cycle after treatment with NGF. D283trk cells $\left(2.5 \times 10^{6}\right)$ were incubated with or without NGF for various lengths of time (6-96 hr as indicated on the $x$-axis in $B$ and $C$ ) and stained with $50 \mu \mathrm{g} / \mathrm{ml}$ propidium iodide (PI) in hypotonic buffer $(0.1 \%$ sodium citrate plus $0.1 \%$ Triton $\mathrm{X}-100)$ at $4^{\circ} \mathrm{C}$ overnight. The PI fluorescence of individual nuclei (10,000 events) was measured using a FACScan flow cytometer $(A)$. The total number of cells was counted using trypan blue. $A, B$, After treatment with NGF for 24 hr and beyond, the percentage of cells in S phase ( $S$ in $A, a$ ) decreased by $43 \%$ compared with no NGF treatment (compare $a$ with $b$ in $A$ ) and compare $-N G F$ with $+N G F$ in $B$, whereas reductions in the percentage of cells in the $\mathrm{G} 0 / \mathrm{G} 1$ and $\mathrm{G} 2 / \mathrm{M}$ phases of the cell cycle were less prominent $(A, B)$. By $72 \mathrm{hr}$, however, reductions in all phases of the cell cycle can be observed (see $c$ and $d$ in $A$ and $B$ ). The asterisk marks the position of cellular debris that is generated from dead cells. $C$, Although a loss in the absolute number of D283trk cells is evident in each phase of the cell cycle, the largest losses are seen in S phase. Note the different scale used for the $y$-axis in D283trk cells with $(-N G F$, left $)$ and without $(+N G F$, right $)$ treatment.

activation of Ras (Li et al., 1992; Thomas et al., 1992; Wood et al., 1992). Accordingly, because mice deficient in rasGAP, a negative regulator of Ras, display a striking increase in the apoptotic death of cells of the anterior neural tube and cranial neural crest (Henkemeyer et al., 1995), it will be important to determine whether apoptosis in TrkA expressing medulloblastoma cells also is mediated by Ras activation. Alternatively, it is possible that other kinases or molecules involved in some other signaling pathways also could play a role in the induction of apoptosis by NGF in medulloblastoma cells. For example, a recent study demonstrated that apoptosis induced by NGF withdrawal in NGFdependent PC12 cells could be mediated by the activation of JNK (c-JUN $\mathrm{NH}_{2}$-terminal protein kinase) and p38 as well as by the concurrent inhibition of extracellular signal-regulated kinase (ERK) signaling pathways (Xia et al., 1995). It will be informative to determine whether downstream events leading to apoptosis in NGF-treated TrkA-expressing medulloblastoma cells also might be mediated by similar signaling pathways.

Our finding that NGF selectively reduces the percentage of D283trk cells in S phase agrees with previous reports that suggest a tight association between DNA synthesis and apoptosis (Qin et al., 1994; Shan and Lee, 1994). In this respect, a conflict in growth and differentiating signals have been postulated to induce inappropriate cell cycle genes that might launch a cascade of events leading to apoptosis (Freeman et al., 1994). Nonetheless, the cell cycle-specific effects of NGF are far from understood at this time. Because our data clearly show that NGF induces autophosphor- ylation of the TrkA receptor in D283trk cells, it is likely that this initial step is shared by signaling pathways leading to cell death as well as to cell survival and differentiation.

Our studies may have important implications for understanding normal development and tumor progression. For example, the induction of apoptosis through activation of the TrkA receptor in TrkA-expressing medulloblastoma cells suggests a novel signaling mechanism that might play a role in normal developmentally regulated programmed cell death, because medulloblastomas resemble embryonic neuroectodermal stem cells or their immature neuronal and glial progeny (Molenaar et al., 1989; Gould et al., 1990; Trojanowski et al., 1994). On the other hand, if the findings reported here reflect the response of TrkA expressing medulloblastoma cells in vivo to NGF, then activation of NGF/TrkA signaling pathways in these tumors may regulate their growth and expansion by inducing apoptosis. Thus, additional studies of these signaling pathways may provide insights into mechanisms that regulate the normal development of the nervous system as well as the induction and progression of medulloblastomas and other pediatric brain tumors.

\section{REFERENCES}

Baker DL, Molenaar WM, Trojanowski JQ Evans AE, Ross AH, Rorke LB, Packer R, Lee VM-Y, Pleasure D (1991) Nerve growth factor receptor expression in peripheral and central primitive neuroectodermal tumors, other pediatric brain tumors and during development of the adrenal gland. Am J Pathol 139:115-122. 
Barbacid M (1995) Neurotrophic factors and their receptors. Curr Opin Cell Biol 7:148-155.

Barker PA, Lomen-Hoerth C, Gensch EM, Meakin SO, Glass DJ, Shooter EM (1993) Tissue-specific alternative splicing generates 2 isoforms of the trk receptor. J Biol Chem 268:15150-15157.

Becker LE, Hinton D (1983) Primitive neuroectodermal tumors of the central nervous system. Hum Pathol 14:538-550.

Berg MM, Sternberg DW, Parada LF, and Chao MV (1992) K-252a inhibits nerve growth factor-induced trk proto-oncogene tyrosine phosphorylation and kinase activity. J Biol Chem 267:13-16.

Cattaneo E, McKay R (1990) Proliferation and differentiation of neuronal stem cells regulated by nerve growth factor. Nature 347:762-765.

Chao MV, Hempstead BL (1995) p75 and Trk: a two receptor system. Trends Neurosci 7:321-326.

Chao MV, Bothwell MA, Ross AH, Koprowski H, Lanahan AA, Buck CR, Sehgal A (1986) Gene transfer and molecular cloning of the human NGF receptor. Science 232:518-521.

Clary DO, Reichardt LF (1994) An alternatively spliced form of the nerve growth factor receptor TrkA confers an enhanced response to neurotrophin 3. Proc Natl Acad Sci USA 91:11133-11137.

Cordon-Cardo C, Tapley P, Jing SQ, Nanduri V, O'Rourke E, Lamballe F, Kovary K, Klein R, Jones KR, Reichardt LF, Barbacid M (1991) The trk tyrosine protein kinase mediates the mitogenic properties of nerve growth factor and neurotrophin-3. Cell 66:173-183.

Deckwerth TL, Johnson EM (1993) Temporal analysis of events associated with programmed cell death (apoptosis) of sympathetic neurons deprived of nerve growth factor. J Cell Biol 123:1207-1222.

Doupe AJ, Landis SC, Patterson PH (1985) Environmental influence in the development of neural crest derivatives: glucocorticoids, growth factors and chromaffin cell plasticity. J Neurosci 5:2119-2142.

Frade J-M, Rodriguez-Tebar A, Barde Y-A (1996) Induction of cell death by endogenous nerve growth factor through its $\mathrm{p} 75$ receptor. Nature 383:166-168.

Freeman RS, Estus S, Johnson EM (1994) Analysis of cell cycle-related gene expression in postmitotic neurons: selective induction of Cyclin D1 during programmed cell death. Neuron 12:343-355.

Friedman HS, Burger PC, Bigner SH, Trojanowski JQ, Wikstrand CJ, Halperin EC, Bigner DD (1985) Establishment and characterization of the human medulloblastoma cell line and transplantable xenograft D283Med. J Neuropathol Exp Neurol 44:592-605.

Gould VE, Jansson DS, Molenaar WM, Rorke LB, Trojanowski JQ, Lee VM-Y, Packer RJ, Franke WW (1990) Primitive neuroectodermal tumors of the central nervous system. Patterns of expression of neuroendocrine markers, and all classes of intermediate filament proteins. Lab Invest 62:498-509.

Greene LA, Tischler A (1976) Establishment of a noradrenergic clonal line of rat adrenal pheochromocytoma cells which respond to nerve growth factor. Proc Natl Acad Sci USA 73:2424-2428.

Hart MN, Earle KM (1973) Primitive neuroectodermal tumors of the brain in children. Cancer 32:890-897.

Hempstead BL, Rabin SJ, Kaplan L, Reid S, Parada LF, Kaplan DR (1992) Overexpression of the trk tyrosine kinase rapidly accelerates nerve growth factor-induced differentiation. Neuron 9:883-896.

Henkemeyer M, Rossi DJ, Holmyard DP, Puri MC, Mbamalu G, Harpal K, Shih TS, Jacks T, Pawson T (1995) Vascular system defects and neuronal apoptosis in mice lacking Ras GTPase-activating protein. Nature 377:695-701.

Ip NY, Stitt TN, Tapley P, Klein R, Glass DJ, Fandl J, Greene LA, Barbacid M, Yancopoulos GD (1993) Similarities and differences in the way neurotrophins interact with the Trk receptors in neuronal and nonneuronal cells. Neuron 10:137-149.

Johnson D, Lanahan A, Buck CR, Sehgal A, Morgan C, Mercer E, Bothwell M, Chao MV (1986) Expression and structure and the human NGF receptor. Cell 47:545-554.

Kaplan DR, Stephens RM (1994) Neurotrophin signal transduction by the Trk receptor. J Neurobiol 25:1404-1417.

Kaplan DR, Hempstead BL, Martin-Zanca D, Chao MV, Parada LF (1991a) The trk proto-oncogene product: a signal transducing receptor for nerve growth factor. Science 252:554-548.

Kaplan DR, Martin-Zanca D, Parada LF (1991b) Tyrosine phosphorylation and tyrosine kinase activity of the trk proto-oncogene product induced by NGF. Nature 350:158-160.

Klein R, Jing SQ, Nanduri V, O'Rourke E, Barbacid M (1991a) The trk proto-oncogene encodes a receptor for nerve growth factor. Cell 65:189-197.
Klein R, Nanduri V, Jing SA, Lamballe F, Tapley P, Bryant S, CordonCardo C, Jones KR, Reichardt LF, Barbacid M (1991b) The trkB tyrosine protein kinase is a receptor for brain-derived neurotrophic factor and neurotrophin-3. Cell 66:395-403.

Lamballe F, Klein R, Barbacid M (1991) trkC, a new member of the trk family of tyrosine protein kinases, is a receptor for neurotrophin-3. Cell 66:967-979.

Levi-Montalcini R, Angeletti P (1968) Nerve growth factor. Physiol Rev 48:534-569.

Li BQ, Kaplan DR, Kung HF, Kamata T (1992) Nerve growth factor stimulation of the Ras-guanine nucleotide exchange factor and GAP activities. Science 256:1456-1459.

Li Y, Holtman DM, Kromer LF, Kaplan DR, Chua-Couzens J, Clary DO, Knusel B, Mobley WC (1995) Regulation of TrkA and ChAT expression in developing rat basal forebrain: evidence that both exogenous and endogenous NGF regulate differentiation of cholinergic neurons. J Neurosci 15:2888-2905.

Lillien L, Claude P (1985) Nerve growth factor is a mitogen for cultured chromaffin cells. Nature 317:632-634.

Lindsay RM, Wiegand SJ, Altar CA, DiStefano PS (1994) Neurotrophic factors: from molecule to man. Trends Neurosci 17:182-190.

Loeb DM, Maragos J, Martin-Zanca D, Chao MV, Parada LF, Greene LA (1991) The trk proto-oncogene rescues NGF responsiveness in mutant NGF-nonresponsive PC12 cell lines. Cell 66:961-966.

Mahadeo D, Kaplan L, Chao MV, Hempstead BL (1994) High affinity nerve growth factor binding displays a faster rate of association than p140trk binding. Implications for multi-subunit polypeptide receptors. J Biol Chem 269:6884-6891.

Markowitz D, Goff S, Bank A (1988) Construction and use of a safe and efficient amphotropic packaging cell line. Virology 167:400-406.

Miller AD, Rosman GJ (1989) Improved retroviral vectors for gene transfer and expression. Biotechniques 7:980-982.

Mills JC, Wang S, Erecinska M, Pittman RN (1995) Use of cultured neurons, and neuronal cell lines to study morphological, biochemical, molecular changes occurring in cell death. Methods Cell Biol 46:217-242.

Mobley WC, Schenker A, Schooter EM (1976) Characterization and isolation of proteolytically modified nerve growth factor. Biochemistry 15:5543-5551.

Mobley WC, Woo JE, Edwards RH, Riopelle RJ, Longo FM, Weskamp G, Otten U, Valletta JS, Johnston MV (1989) Developmental regulation of nerve growth factor and its receptor in the rat caudate putamen. Neuron 3:655-664.

Molenaar WN, Jansson DS, Gould VE, Rorke LB, Franke WW, Lee VM-Y Packer RJ, Trojanowski JQ (1989) Molecular markers of primitive neuroectodermal tumors and other pediatric central nervous system tumors. Monoclonal antibodies to neuronal and glia antigens distinguish subsets of primitive neuroectodermal tumors. Lab Invest 61:635-643.

Muragaki Y, Timothy N, Leight S, Hempstead BL, Chao MV, Trojanowski JQ, Lee VM-Y (1995) Expression of trk receptors in the developing and adult human central and peripheral nervous system. J Comp Neurol 356:387-397.

Nakagawara A, Arima M, Azar CG, Scavarda NJ, Brodeur GM (1992) Inverse relationship between trk expression and $\mathrm{N}$-myc amplification in human neuroblastomas. Cancer Res 52:1364-1368.

Nakagawara A, Arima-Nakagawara M, Scavarda NJ, Azar CG, Cantor AB, Brodeur GM (1993) Association between high levels of expression of the trk gene and favorable outcome in human neuroblastoma. N Engl J Med 328:847-854.

Nicoletti I, Migliorati G, Pagliacci MC, Grignani F, Riccardi C (1991) A rapid and simple method for measuring thymocyte apoptosis by propidium iodide staining and flow cytometry. J Immunol Methods 139:271-279.

Peringa J, Fung K-M, Muragaki Y, Trojanowski JQ (1995) The cellular and molecular biology of medulloblastoma. Curr Opin Neurol 8:437-440.

Pittman RN, Wang S, DiBenedetto AJ, Mills JC (1993) A system for characterizing cellular and molecular events in programmed neuronal cell death. J Neurosci 13:3669-3680.

Pleasure SJ, Reddy UR, Venkatakrishnan G, Roy AK, Chen J, Ross AH, Trojanowski JQ, Pleasure DE, Lee VM-Y (1990) Introduction of nerve growth factor (NGF) receptors into a medulloblastoma cell line results in expression of high- and low-affinity NGF receptors but not NGF-mediated differentiation. Proc Natl Acad Sci USA 87:8496-8500. 
Qin XQ, Livingston DM, Kaelin WG, Adams PD (1994) Deregulated transcription factor E2F-1 expression leads to S phase entry and p53mediated apoptosis. Proc Natl Acad Sci USA 91:10918-10922.

Radeke MJ, Misko TP, Hsu C, Herzenberg LA, Shooter EM (1987) Gene transfer and molecular cloning of the rat nerve growth factor receptor. Nature 325:593-597.

Rorke LB (1983) The cerebellar medulloblastoma and its relationship to primitive neuroectodermal tumors. J Neuropathol Exp Neurol 42:1-15.

Rorke LB, Gilles FH, Davis RL, Becker LE (1985) Revision of the World Health Organization classification of brain tumors for childhood brain tumors. 56:1869-1886.

Segal RA, Goumnerova LC, Kwon YK, Stiles CD, Pomeroy SL (1994) Expression of the neurotrophin receptor Trk $\mathrm{C}$ is linked to a favorable outcome in medulloblastoma. Proc Natl Acad Sci USA 91:12867-12871.

Shan B, Lee WH (1994) Deregulated expression of E2F-1 induces S-phase entry and leads to apoptosis. Mol Cell Biol 14:8166-8173.

Schiffer D, Cavalla P, Chio A, Giordana MT, Marino S, Mauro A, Migheli A (1994) Tumor cell proliferation and apoptosis in medulloblastoma. Acta Neuropathol (Berl) 87:362-370.

Stephens RM, Loeb DM, Copeland TD, Pawson T, Greene LA, Kaplan DR (1994) Trk receptors use redundant signal transduction pathways involving SHC and PLC- $\gamma 1$ to mediate NGF responses. Neuron 12:691-705.

Thomas SH, DeMarco M, D’Arcangelo G, Halegoua S, Brugge JS (1992) Ras is essential for nerve growth factor and phorbol ester induced tyrosine phosphorylation of MAP kinases. Cell 68:1031-1040.

Tilly JL, Hsueh AJ (1993) Microscale autoradiographic method for the qualitative and quantitative analysis of apoptotic DNA fragmentation. J Cell Physiol 154:519-526.

Tischler AS, Riseberg JC, Hardenbrook MA, Cherington V (1993) Nerve growth factor is a potent inducer of proliferation and neuronal differentiation for adult rat chromaffin cells in vitro. J Neurosci 13:1533-1542.
Tremblay GF, Lee VM-Y, Trojanowski JQ (1985) Expression of vimentin, glial filament, and neurofilament in primitive childhood brain tumors. A comparative immunoblot and immunoperoxidase study. Acta Neuropathol (Berl) 68:239-244.

Trojanowski JQ Kelsten ML, Lee VM-Y (1989) Phosphate dependent and independent neurofilament epitopes are expressed throughout the cell cycle in rapidly dividing human medulloblastoma cells. Am J Pathol 135:747-758.

Trojanowski JQ, Fung K-M, Rorke LB, Tohyama T, Yachnis AT, Lee VM-Y (1994) In vivo and in vitro models of medulloblastomas and other primitive neuroectodermal brain tumors of childhood. Mol Chem Neuropathol 21:219-239.

Unsicker K, Drisch B, Otten J, Thoenen H (1978) Nerve growth factorinduced fiber outgrowth from isolated rat adrenal chrommaffin cells: impairment by glucocorticoids. Proc Natl Acad Sci USA 75:3498-3502.

Verdi JM, Birren SJ, Ibanez CF, Persson H, Kaplan DR, Benedetti M, Chao MV, Anderson DJ (1994) p75 ${ }^{\text {LNGFR }}$ regulates Trk signal transduction and NGF-induced neuronal differentiation in MAH cells. Neuron $12: 733-745$.

Washiyama K, Muragaki Y, Rorke LB, Lee VM-Y, Feinstein SC, Radeke MJ, Blumberg D, Kaplan DR, Trojanowski JQ (1996) Neurotrophin and neurotrophin receptor proteins in medulloblastomas and other primitive neuroectodermal tumors of the pediatric central nervous system. Am J Pathol 148:929-940.

Wood W, Sarnecki C, Roberts TM, Blenis J (1992) Ras mediates nerve growth factor receptor modulation of three signal-transducing protein kinases: MAP kinases, Raf-1, and RSK. Cell 68:1041-1050.

Xia Z, Dickens M, Raingeaud J, Davis RJ, Greenberg ME (1995) Opposing effects of ERK and JNK-p38 MAP kinases on apoptosis. Science 270:1326-1331.

Yao R, Cooper GM (1995) Requirement for phosphatidylinositol-3 kinase in the prevention of apoptosis by nerve growth factor. Science 267:2003-2006. 